Prepared in cooperation with Fort Irwin National Training Center

\title{
Analysis of Potential Water-Supply Management Options, 2010-60, and Documentation of Revisions to the Model of the Irwin Basin Aquifer System, Fort Irwin National Training Center, California
}

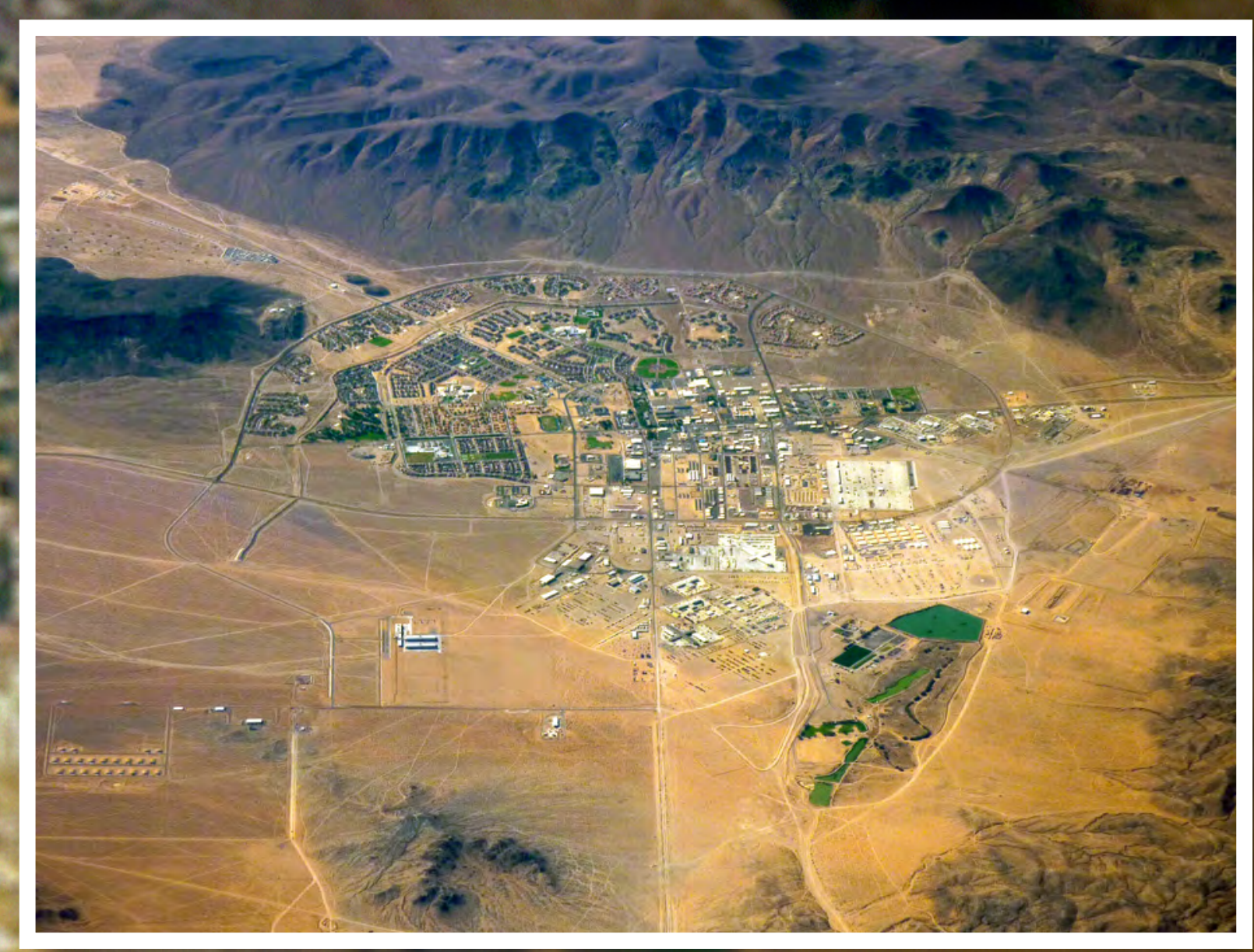

Scientific Investigations Report 2014-5081

U.S. Department of the Interior U.S. Geological Survey 
Cover. Aerial view of Fort Irwin Military Reservation, Fort Irwin, California. Photo taken by Bobak Ha'Eri, on July 27, 2009. 


\section{Analysis of Potential Water-Supply Management Options, 2010-60, and Documentation of Revisions to the Model of the Irwin Basin Aquifer System, Fort Irwin National Training Center, California}

By Lois M. Voronin, Jill N. Densmore, and Peter Martin

Prepared in cooperation with Fort Irwin National Training Center

Scientific Investigations Report 2014-5081 


\title{
U.S. Department of the Interior SALLY JEWELL, Secretary
}

\section{U.S. Geological Survey Suzette M. Kimball, Acting Director}

\author{
U.S. Geological Survey, Reston, Virginia: 2014
}

For more information on the USGS - the Federal source for science about the Earth, its natural and living resources, natural hazards, and the environment, visit http://www.usgs.gov or call 1-888-ASK-USGS.

For an overview of USGS information products, including maps, imagery, and publications, visit http://www.usgs.gov/pubprod

To order this and other USGS information products, visit http://store.usgs.gov

Any use of trade, firm, or product names is for descriptive purposes only and does not imply endorsement by the U.S. Government.

Although this information product, for the most part, is in the public domain, it also may contain copyrighted materials as noted in the text. Permission to reproduce copyrighted items must be secured from the copyright owner.

Suggested citation:

Voronin, L.M., Densmore, J.N., and Martin, Peter, 2014, Analysis of potential water-supply management options, 2010-60, and documentation of revisions to the model of the Irwin Basin Aquifer System, Fort Irwin National Training Center, California: U.S. Geological Survey Scientific Investigations Report 2014-5081, 34 p., http://dx.doi.org/10.3133/sir20145081.

ISSN 2328-0328 (online) 


\section{Contents}

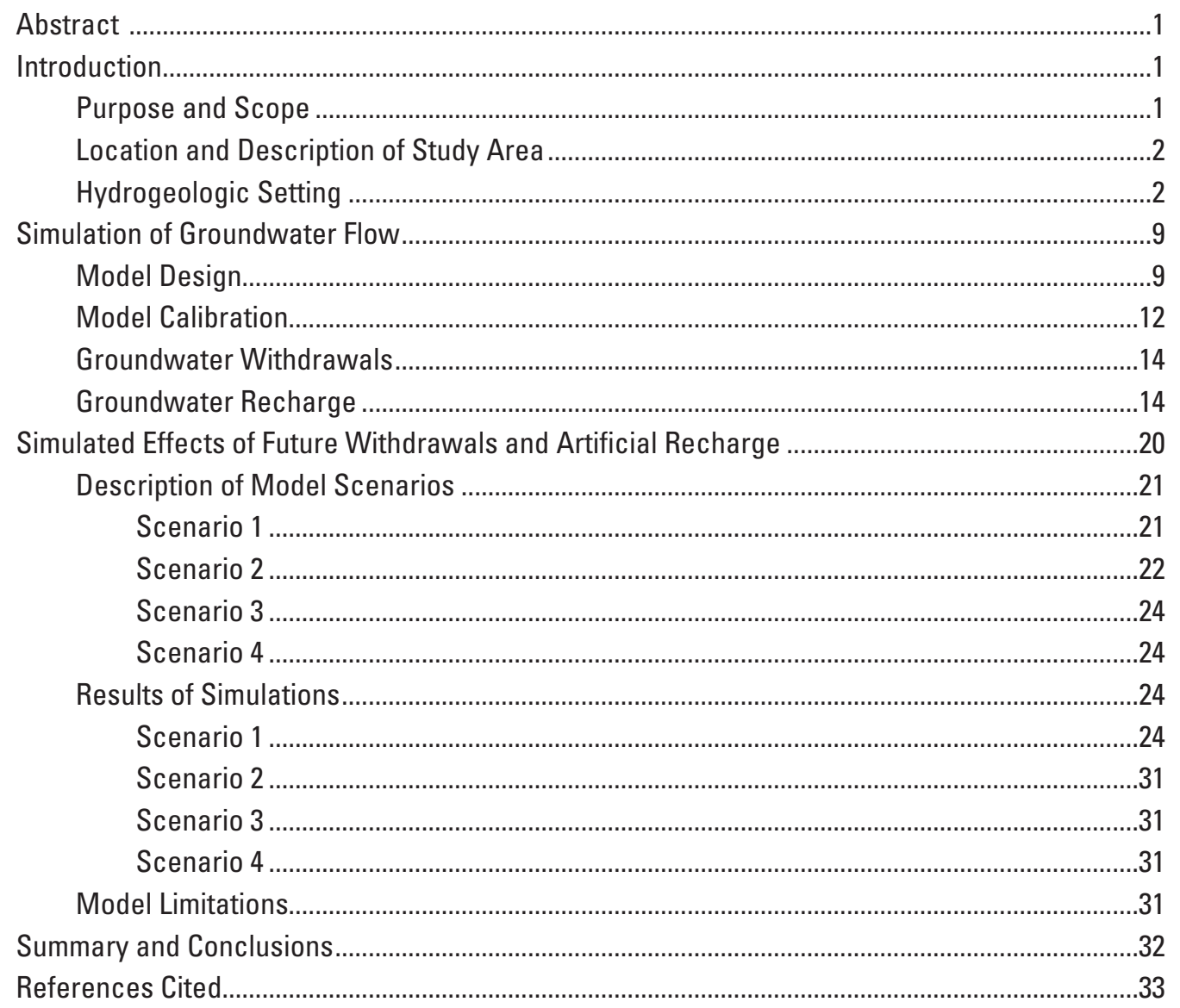




\section{Figures}

1. Map showing location of study area at Fort Irwin National

Training Center, California

2. Generalized map of the Irwin Basin, Fort Irwin National

Training Center, California

3. Figures showing generalized geology of the Irwin Basin, Fort Irwin

National Training Center, California.....

4. Figure showing altitude of the basement complex and boundaries of groundwater model layers for the Irwin Basin, Fort Irwin National

Training Center, California

5. Cross-sectional view of model layers, hydraulic conductivities, and boundary conditions of the Irwin Basin, Fort Irwin National Training Center, California

6. Map showing simulated 1994 hydraulic heads, layer 1, Irwin Basin, Fort Irwin National Training Center, California.

7. Hydrographs of measured water levels and simulated hydraulic heads in 11 observation wells, Irwin Basin, Fort Irwin National Training Center, California.

8. Graph showing annual groundwater recharge and withdrawals from Bicycle, Irwin, and Langford Basins, Fort Irwin National Training Center, California, 1941-2010.

9. Hydrographs of measured water levels and simulated hydraulic heads in six observation wells near the wastewater-treatment facility, Irwin Basin, Fort Irwin National Training Center, California.....

10. Graph showing average 2001 to 2010 total monthly groundwater withdrawal distribution for wells in the Bicycle, Irwin, and Langford Basins that were used to provide water to Fort Irwin National Training Center, California

11. Map showing simulated difference in hydraulic head from October 2010 conditions to October 2060 conditions, scenario 1, layer 1, Irwin Basin, Fort Irwin National Training Center, California.

12. Simulated difference in hydraulic head from 0 ctober 2010 conditions to October 2060 conditions, scenario 2, layer 1, Irwin Basin, Fort Irwin National Training Center, California

13. Map showing simulated difference in hydraulic head from October 2010 conditions to October 2060 conditions, scenario 3, layer 1, Irwin Basin, Fort Irwin National Training Center, California.

14. Map showing simulated difference in hydraulic head from October 2010 conditions to October 2060 conditions, scenario 4, layer 1, Irwin Basin, Fort Irwin National Training Center, California.

15. Hydrographs of simulated hydraulic heads at 14 wells for four scenarios, Irwin Basin, Fort Irwin National Training Center, California 


\section{Tables}

1. Simulated volumetric budget, for 1994 conditions (stress period 54 ), from the A) original, MODFLOW-88 model and B) 2010 model, Irwin Basin, Fort Irwin National Training Center, California ..........................................................................14

2. Simulated annual 1941-2010 groundwater recharge and withdrawals, Irwin Basin, Fort Irwin National Training Center, California.

3. Summary of 2001-10 groundwater withdrawals, and estimates of evapotranspiration, evaporation, and recharge used in the 2010 model and model scenarios, Irwin Basin, Fort Irwin National Training Center, California

4. Summary of simulated monthly groundwater withdrawals from wells in the Irwin Basin used in the four scenarios, Irwin Basin, Fort Irwin National Training Center, California

5. Simulated hydraulic head at 14 wells for four model scenarios, Irwin Basin, Fort Irwin National Training Center, California.

6. Summary of simulated groundwater discharge to drains, Irwin Basin, Fort Irwin National Training Center, California. .31 


\section{Conversion Factors}

Inch/Pound to SI

\begin{tabular}{|c|c|c|}
\hline Multiply & By & To obtain \\
\hline \multicolumn{3}{|c|}{ Length } \\
\hline inch (in.) & 2.54 & centimeter $(\mathrm{cm})$ \\
\hline inch (in.) & 25.4 & millimeter $(\mathrm{mm})$ \\
\hline foot $(\mathrm{ft})$ & 0.3048 & meter $(\mathrm{m})$ \\
\hline mile (mi) & 1.609 & kilometer $(\mathrm{km})$ \\
\hline \multicolumn{3}{|c|}{ Area } \\
\hline square mile $\left(\mathrm{mi}^{2}\right)$ & 259.0 & hectare (ha) \\
\hline square mile $\left(\mathrm{mi}^{2}\right)$ & 2.590 & square kilometer $\left(\mathrm{km}^{2}\right)$ \\
\hline \multicolumn{3}{|c|}{ Volume } \\
\hline acre-foot (acre-ft) & 1,233 & cubic meter $\left(\mathrm{m}^{3}\right)$ \\
\hline acre-foot (acre-ft) & 0.001233 & cubic hectometer $\left(\mathrm{hm}^{3}\right)$ \\
\hline \multicolumn{3}{|c|}{ Flow rate } \\
\hline acre-foot per year (acre-ft/yr) & 1,233 & cubic meter per year $\left(\mathrm{m}^{3} / \mathrm{yr}\right)$ \\
\hline acre-foot per year (acre-ft/yr) & 0.001233 & cubic hectometer per year $\left(\mathrm{hm}^{3} / \mathrm{yr}\right)$ \\
\hline foot per day (ft/d) & 0.3048 & meter per day $(\mathrm{m} / \mathrm{d})$ \\
\hline cubic foot per day $\left(\mathrm{ft}^{3} / \mathrm{d}\right)$ & 0.02832 & cubic meter per day $\left(\mathrm{m}^{3} / \mathrm{d}\right)$ \\
\hline gallon per minute (gal/min) & 0.06309 & liter per second $(\mathrm{L} / \mathrm{s})$ \\
\hline acre-feet per month (acre-ft/mo) & 0.000469 & cubic meters per second $\left(\mathrm{m}^{3} / \mathrm{s}\right)$ \\
\hline \multicolumn{3}{|c|}{ Hydraulic conductivity } \\
\hline foot per day $(\mathrm{ft} / \mathrm{d})$ & 0.3048 & meter per day $(\mathrm{m} / \mathrm{d})$ \\
\hline
\end{tabular}

Temperature in degrees Fahrenheit $\left({ }^{\circ} \mathrm{F}\right)$ may be converted to degrees Celsius $\left({ }^{\circ} \mathrm{C}\right)$ as follows:

${ }^{\circ} \mathrm{C}=\left({ }^{\circ} \mathrm{F}-32\right) / 1.8$

Vertical coordinate information is referenced to North American Vertical Datum of 1988 (NAVD 88).

Altitude, as used in this report, refers to distance above the vertical datum. 


\section{Abbreviations}

$\begin{array}{ll}\text { ASL } & \text { above sea level } \\ \text { CIMIS } & \text { California Irrigation Management Information System } \\ \text { GMG } & \text { Geometric Multigrid Solver } \\ \text { MODFLOW-88 } & \text { USGS Modular Three-Dimensional Finite-Difference Groundwater Flow-Model } \\ \text { NAVD 88 } & \text { North American Vertical Datum of 1988 } \\ \text { NTC } & \text { Fort Irwin National Training Center } \\ \text { USGS } & \text { U.S. Geological Survey }\end{array}$




\section{Acknowledgments}

The authors thank the following personnel at Fort Irwin NTC: Justine Dishart, Muhammed Bari, and Chris Woodruff for providing groundwater withdrawal data. 


\title{
Analysis of Potential Water-Supply Management Options, 2010-60, and Documentation of Revisions to the Model of the Irwin Basin Aquifer System, Fort Irwin National Training Center, California
}

\author{
By Lois M. Voronin, Jill N. Densmore, and Peter Martin
}

\begin{abstract}
The Fort Irwin National Training Center is considering several alternatives to manage their limited water-supply sources in the Irwin Basin. An existing threedimensional, finite-difference groundwater-flow modelthe U.S. Geological Survey's MODFLOW — of the aquifer system in the basin was updated and the initial input dataset was supplemented with groundwater withdrawal data for the period 2000-10. The updated model was then used to simulate four combinations, or scenarios, of groundwater withdrawal and recharge over the next 50 years (January 2011 through December 2060). The scenarios included combinations of continuing withdrawals from currently active production wells, supplementing any increases in demand with withdrawals from an inactive production well, reducing withdrawal amounts and rates, and reducing the discharge of treated wastewater to infiltration ponds that provide a recharge source to the underlying aquifer. Results of the simulations indicated that, depending on the scenario implemented, groundwater levels would rise (over the next 50 years) from 40 feet to as much as 65 feet in the northwestern part of the Irwin Basin, and from 5 feet to 10 feet in the southeastern part.
\end{abstract}

\section{Introduction}

Fort Irwin National Training Center (Fort Irwin NTC) in the Mojave Desert of California has been used as a military training facility almost continuously since August 1940. The training center currently (2012) obtains its potable water supply by pumping from wells in the Irwin, Bicycle, and Langford Basins. Groundwater development began in the Irwin Basin in 1941. From 1941 to 1996, most of the groundwater pumpage was from the Irwin Basin which resulted in water-level declines of about $30 \mathrm{ft}$ in the basin during this period. Pumping from the Bicycle and Langford Basins began in 1967 and 1992, respectively, and pumping from these basins has resulted in a decrease in the groundwater demand from the Irwin Basin. Since 1991, the combined pumping from the adjacent Bicycle and the Langford Basins has exceeded that in the Irwin Basin. Since the 1990's, reduced pumping and artificial recharge of wastewater and irrigation in the Irwin Basin has caused water levels to stabilize or rise throughout the basin. Although water levels are currently rising in the Irwin Basin, treated wastewater that percolates through evaporate deposits underlying the wastewatertreatment facility and infiltration/holding ponds has resulted in high concentrations of dissolved solids in groundwater that is migrating toward the pumping-caused depression in water levels near the center of the basin (Densmore and Londquist, 1997). Water-quality concerns have led to the abandonment or destruction of several production wells in the Irwin Basin.

To effectively manage the water resources and plan for future water needs at the Fort Irwin NTC, it is important to have a complete understanding of the hydrogeologic and geochemical framework of the Irwin, Langford, and Bicycle Basins. To provide the information needed to develop that understanding, the U.S. Geological Survey (USGS), in cooperation with the Fort Irwin NTC, conducted a series of studies to evaluate the hydrogeologic system and conditions at the training center. This report describes the results of one of those studies.

\section{Purpose and Scope}

This report describes the results of the simulation of groundwater flow in the aquifer system in the Irwin Basin at the Fort Irwin NTC, California, using an existing groundwater-flow model developed by Densmore (2003) that was updated to run with MODFLOW 2005, the most current version of the USGS three-dimensional, finite-difference groundwater model, and to use groundwater withdrawal data for the period 2000-10. The original model simulated the hydrologic conditions of the Irwin Basin for the period 1941-99. This report describes the hydrogeology of the Irwin Basin, the 
updates made to the existing model, and the results of the simulation of four scenarios of hypothetical combinations of groundwater recharge and withdrawal over the next 50 years. The updated groundwater-flow model is a useful tool to help estimate the long-term availability of groundwater from the basin by evaluating differences in groundwater-level altitudes (or water levels) among scenarios simulating different withdrawal and recharge rates. The updated model was used to evaluate the potential spatial effects on groundwater levels as a consequence of 1) continued withdrawals at the 2010 average rate of pumping, 2) supplementing water-supply needs with withdrawals from an inactive production well, 3 ) a reduction in groundwater recharge from treated wastewater.

\section{Location and Description of Study Area}

The Fort Irwin NTC is about 130 miles (mi) northeast of Los Angeles and $35 \mathrm{mi}$ northeast of Barstow in southern California (fig. 1). The training center covers about $970 \mathrm{mi}^{2}$ (square miles) of the northern part of the Mojave Desert and encompasses several ground-water basins. Wells in the Irwin, Bicycle, and Langford Basins currently supply water to the base (fig. 1).

The Irwin Basin has a fairly flat floor bordered to the east by Beacon Hill, to the north-northwest by Northwest Ridge, to the west by Southwest Ridge, and to the south by low-lying hills that separate the Irwin Basin from the Langford Basin (fig. 2). The surface-water drainage area of the basin is about $30 \mathrm{mi}^{2}$ and the floor of the basin is about $7 \mathrm{mi}^{2}$. There are no perennial streams in the basin but several dry washes convey surface flow during, or immediately after, large storms. Surface-water flow out of the basin, when it occurs, is to the southeast into the Langford Basin, through an unnamed ephemeral wash near Garlic Spring (fig. 2).

The basin climate is typical of the Mojave Desert, with scant precipitation, hot summers, and cool winters. There are no official weather records for the Irwin Basin itself, but at Goldstone, about 15 mi northwest of the basin (fig. 1), 1973-2006 average annual precipitation is about 5.8 in. (inches), most of which falls during the winter, with a few isolated thunderstorms during the summer. At Barstow, 35 mi southwest of the basin, 1997-2011 average annual precipitation is about 5.1 in. Between 1973 and 2011, the annual precipitation at Barstow ranged from about 2.0 in. in 1975 to about 13.2 in. in 2005. Between 1940 and 2013, temperatures at Barstow ranged from $3{ }^{\circ} \mathrm{F}$ to $116^{\circ} \mathrm{F}$ and averaged about $64^{\circ} \mathrm{F}$. The 1997-2011 average annual potential evaporation at Barstow is about 72 in., (National Oceanic and Atmospheric Administration, 1994; EarthInfo, Inc., 1995, 2000; David Inouye, California Department of Water Resources, written commun., 1996; California Irrigation Management Information System, 2013).

\section{Hydrogeologic Setting}

The Irwin Basin is filled with as much as $950 \mathrm{ft}$ of unconsolidated deposits that consist of younger alluvium of Quaternary age and older alluvium of late Tertiary to Quaternary age (Densmore, 2003, fig. 3). The deposits are unconsolidated at land surface and become partly consolidated with depth. The unconsolidated deposits are the only waterbearing material in the basin from which appreciable amounts of groundwater can be obtained. These deposits are underlain by a basement complex of volcanic rocks of Tertiary age and igneous and metamorphic rocks of pre-Tertiary age, which convey insignificant amounts of groundwater except in areas where they are jointed, weathered or fractured.

The older alluvium (fig. 3, QTa and Tl) consists of sand, gravel, and clay derived predominantly from granitic material, except in the northern part of the basin, where volcanic material dominates. Where the older alluvium consists predominantly of sand and gravel, it yields moderate amounts of water to wells. In the southeastern part of the basin, however, the older alluvium consists almost entirely of low-permeability lacustrine deposits (fig. 3, B-B', Tl) of silt and clay. These low-permeability deposits extend from well 14N/3E-33N1 near the center of the basin to well 13N/3E-10E1-3 in the unnamed wash that leads to Garlic Spring, and are bounded by the Garlic Spring Fault on the northeast and an unnamed fault on the southwest.

The younger alluvium (fig. 3, Qa) consists primarily of loose coarse sand and gravel with small amounts of clay. Some thin, discontinuous clay lenses overlie the lacustrine deposits within the older alluvium in the area beneath the former sprinkler-pivot field in the southeastern part of the basin (fig. 2) and may result in a perched water table in this area. Most of the younger alluvium lies above the water table; however, in areas where it is saturated, primarily in the center of the basin, it yields large quantities of water to wells (as much as $1,000 \mathrm{gal} / \mathrm{min}$ ). Wellbore-flow tests of selected base supply wells indicate that most of the water pumped comes from the younger alluvium (Densmore and Londquist, 1997).

The aquifer system in the Irwin Basin consists of an upper aquifer and a lower aquifer. The upper aquifer is unconfined and is contained within the saturated part of the younger alluvium. This aquifer reaches a maximum thickness of about $200 \mathrm{ft}$ in the west-central part of the basin (fig. 3). The lower aquifer is composed of older alluvium and is confined throughout most of the basin. This aquifer reaches a maximum thickness of about $600 \mathrm{ft}$ in the central part of the basin (fig. 3). Although some water is contained in the underlying basement complex, the effective base of the groundwater system is at the top of basement complex. The altitude of the surface of the basement complex in the Irwin Basin is shown in figure 4. 

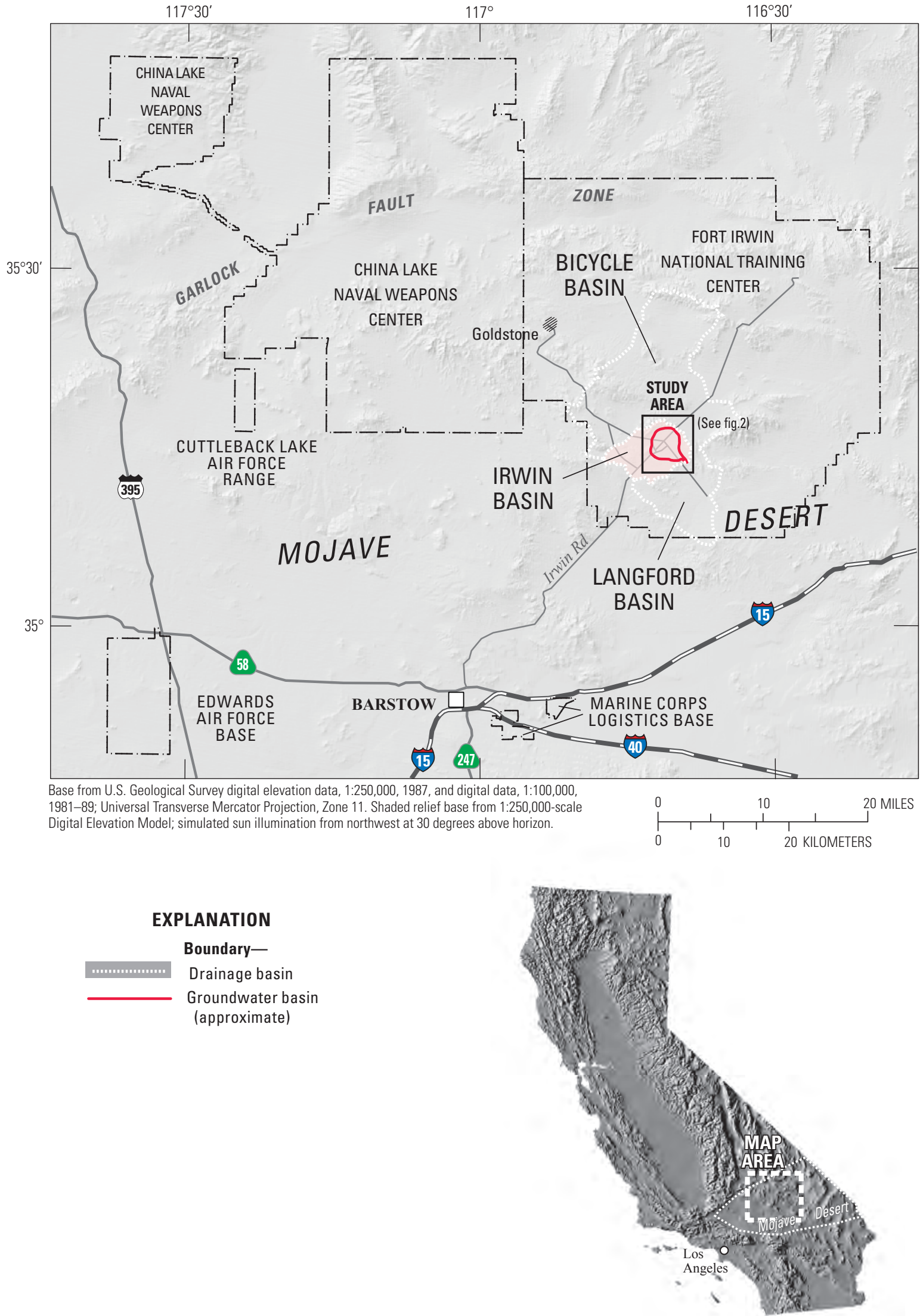

Figure 1. Location of study area at Fort Irwin National Training Center, California 

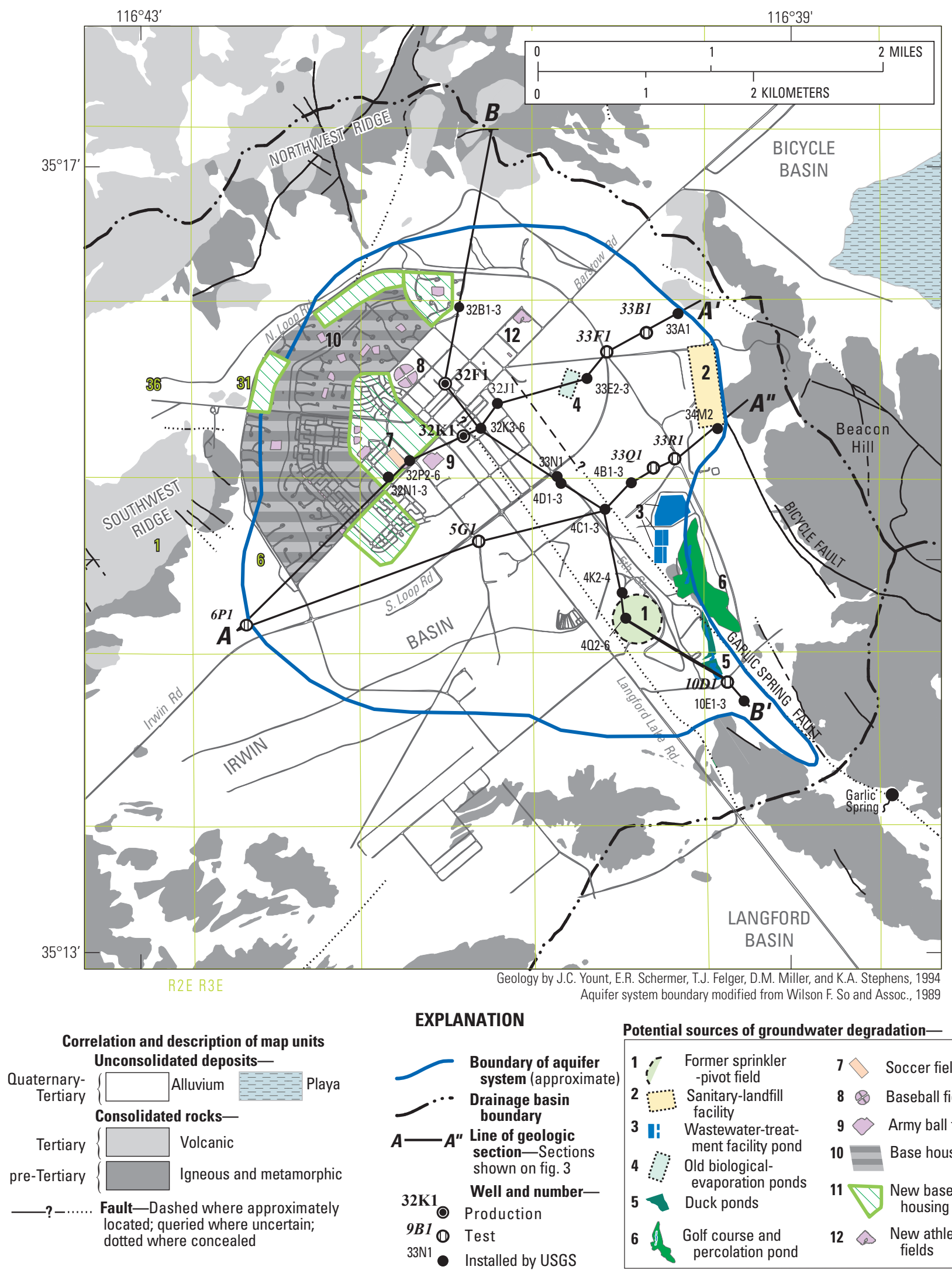

Potential sources of groundwater degradation-

\begin{tabular}{|c|c|c|c|}
\hline & $\begin{array}{l}\text { Former sprinkler } \\
\text {-pivot field }\end{array}$ & $7 \diamond$ & Soccer field \\
\hline 2 & Sanitary-landfill & 88 & Baseball field \\
\hline 3 & Wastewater-treat- & & Army ball field \\
\hline & $\begin{array}{l}\text { ment facility pond } \\
\text { Old biological- }\end{array}$ & & Base housing \\
\hline & evaporation ponds & & New base \\
\hline & Duck ponds & & housing \\
\hline 6 & $\begin{array}{l}\text { Golf course and } \\
\text { percolation pond }\end{array}$ & $12 \Delta$ & $\begin{array}{l}\text { New athletic } \\
\text { fields }\end{array}$ \\
\hline
\end{tabular}

Figure 2. Generalized map of the Irwin Basin, Fort Irwin National Training Center, California. 

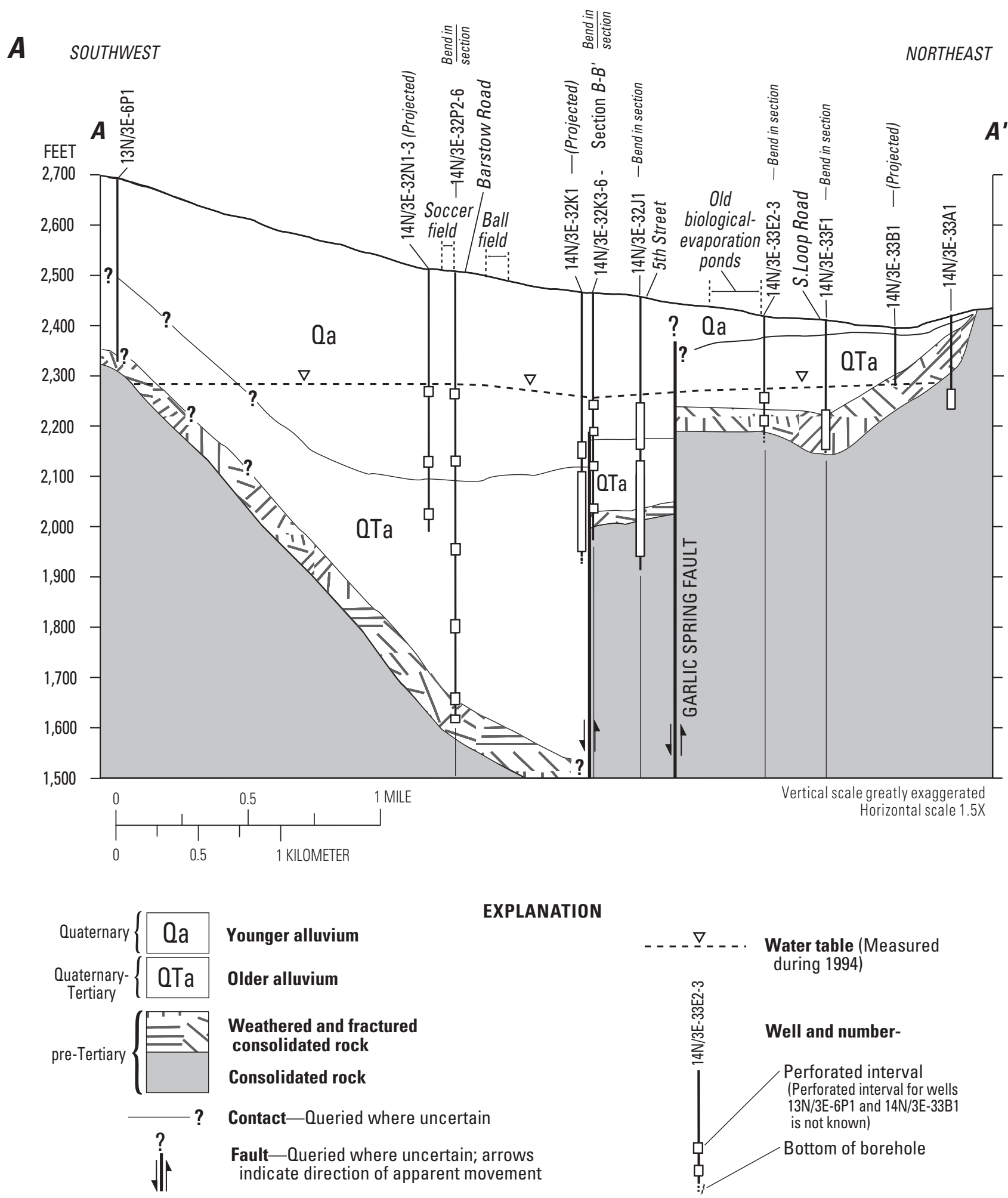

Figure 3. Generalized geology of the Irwin Basin, Fort Irwin National Training Center, California (Densmore, 2003). [Section locations shown in fig. 2] 

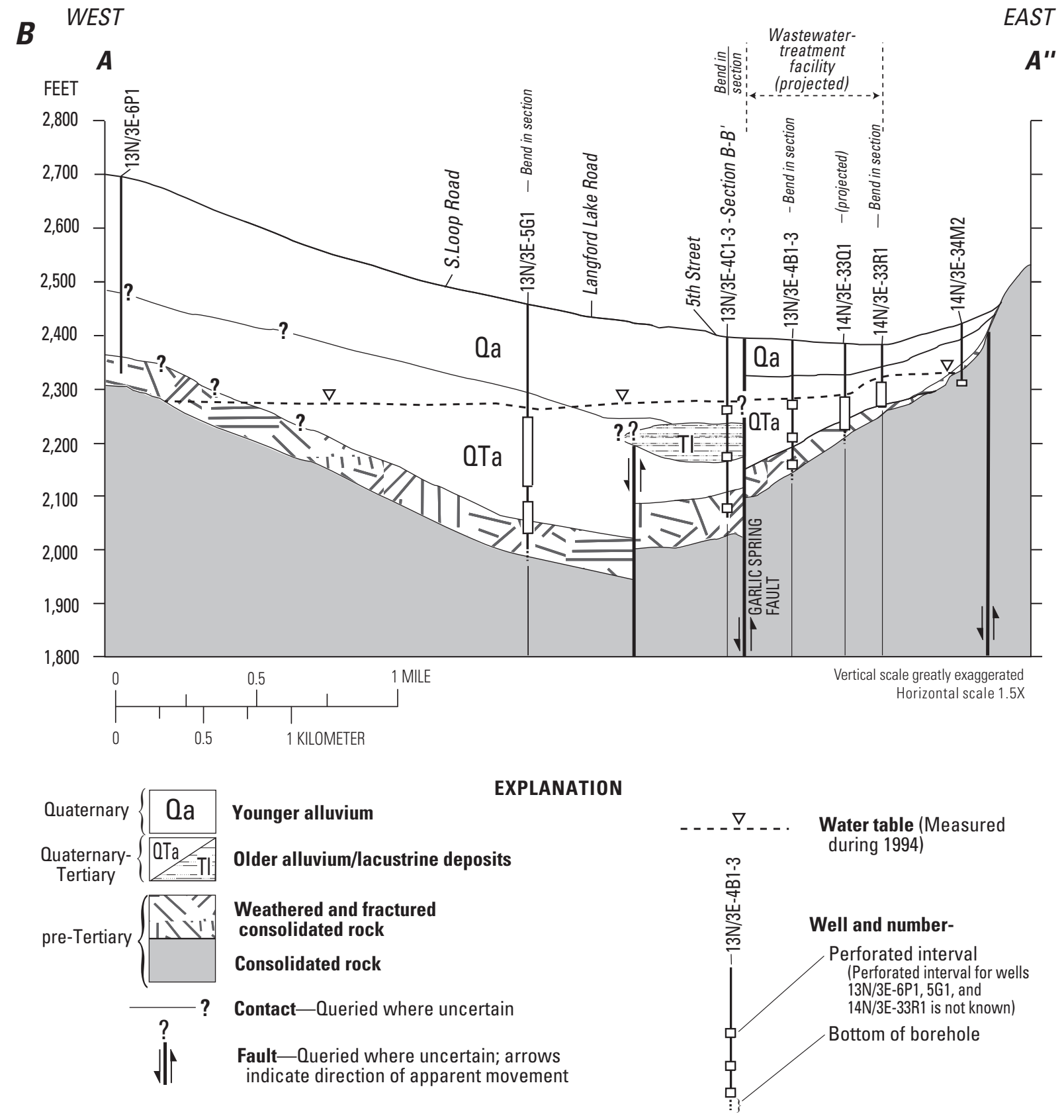

Figure 3. - Continued 
C NORTH

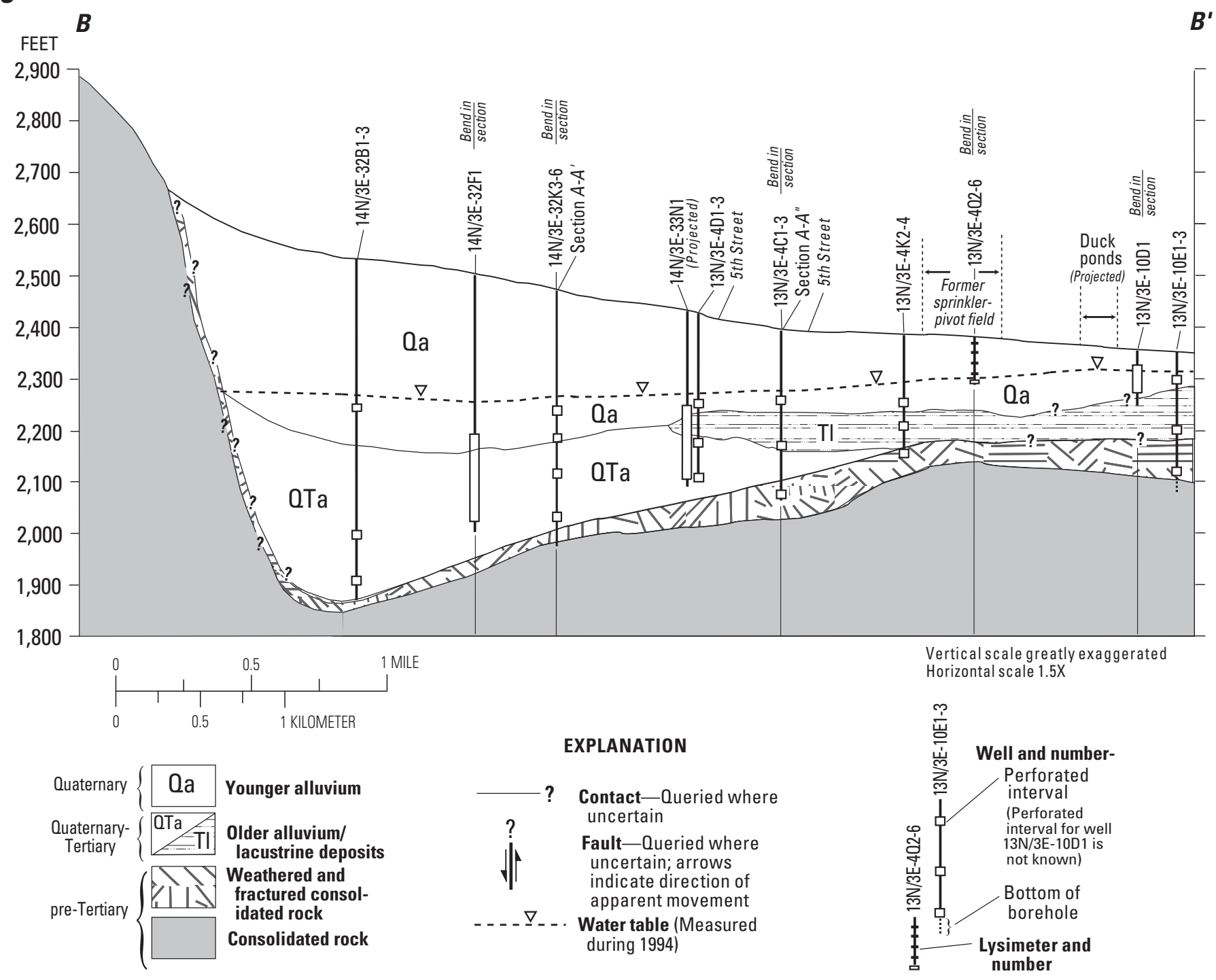

Figure 3. - Continued 

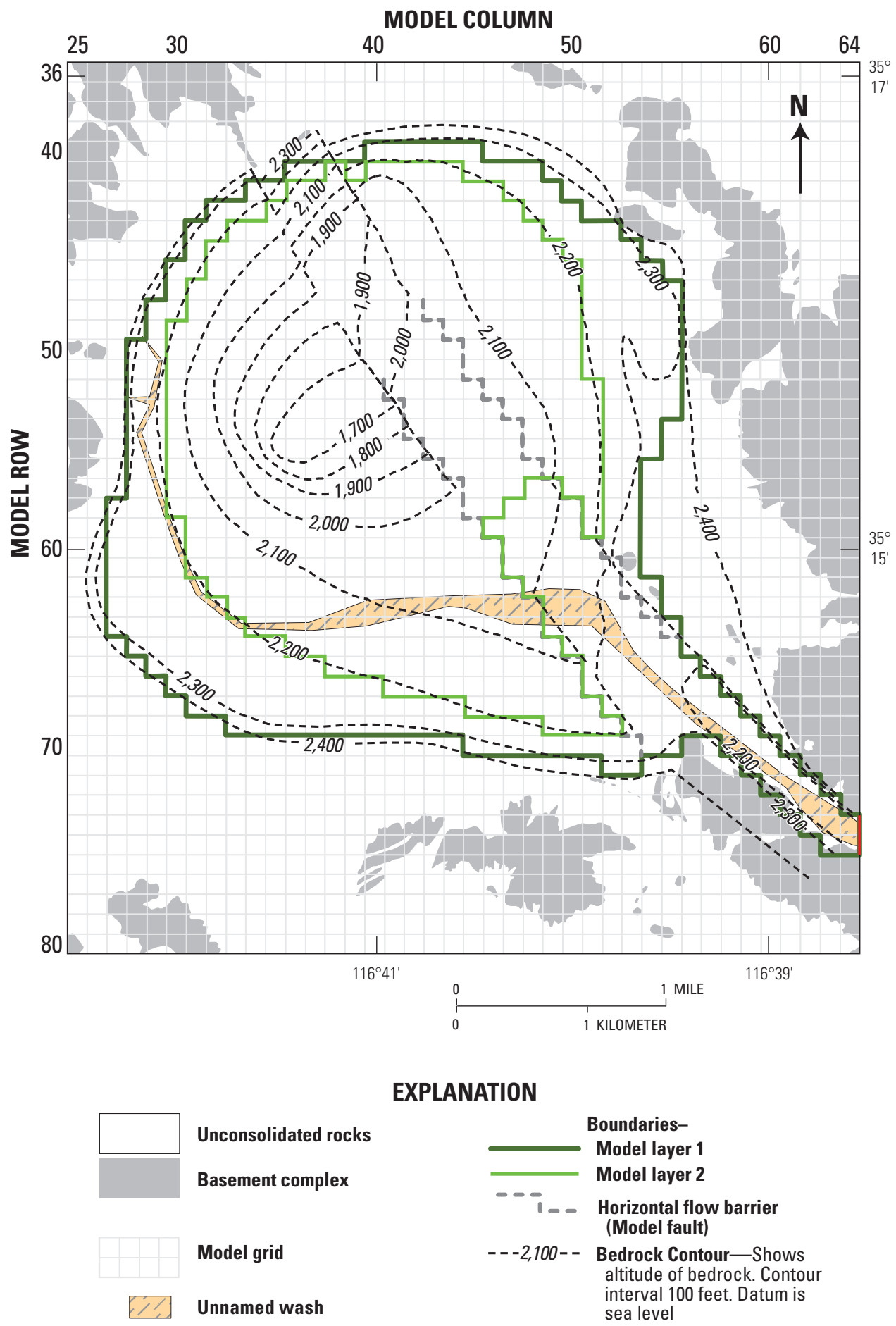

EXPLANATION

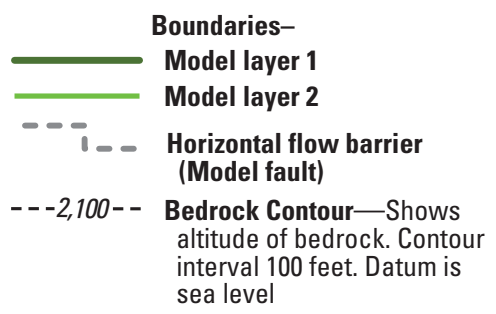

General head

Figure 4. Altitude of the basement complex and boundaries of groundwater model layers for the Irwin Basin, Fort Irwin National Training Center, California (Densmore, 2003). 
Numerous faults have been mapped in the bedrock hills surrounding the Irwin Basin (Yount and others, 1994) (figs. 2, 3); they include the Garlic Spring Fault, the Bicycle Lake Fault, and many unnamed faults. Most of these faults are buried beneath the unconsolidated deposits and thus their presence within the basin is largely unknown. Yount and others (1994) mapped the Garlic Spring Fault into the unconsolidated deposits, suggesting that the fault may cut through both the younger and the older alluvium in the southeastern part of the basin. Water-quality and water-level data, presented by Densmore and Londquist (1997), indicate that the Garlic Spring Fault and a parallel unnamed fault may be acting, in part, as a partial barrier to horizontal groundwater flow, primarily in the lower aquifer. The water-quality data indicate that vertical flow also is being impeded on the west side of the Garlic Spring Fault because of lithologic differences between the younger alluvium and the underlying lacustrine deposits of the older alluvium. Minor compaction and deformation of the water-bearing deposits immediately adjacent to the faults, fault gouge along the fault zone, and cementation of the fault zone by the deposition of minerals from groundwater are believed to create the barrier effect of the faults.

The areal extent of the aquifer system is defined by the intersection of the water table and the surrounding rocks of the basement complex. Under predevelopment conditions (pre-1941), the water table was about 2,300 feet above NAVD88. The boundary of the saturated aquifer system coincides with the 2,300-foot altitude contour of the basement complex shown in figure 4 (the approximate boundary of the aquifer system is shown in figure 2). All the alluvial deposits above this altitude were unsaturated under predevelopment conditions.

\section{Simulation of Groundwater Flow}

An existing groundwater-flow model of the aquifer system in the Irwin Basin (Densmore, 2003) was updated and used to simulate flow under four alternative withdrawal and recharge conditions, here called scenarios. Densmore (2003) developed a two-layer groundwater-flow model for the period 1941-99 for the aquifer system in the Irwin Basin to assess the long-term availability and quality of groundwater, to evaluate groundwater conditions as a result of withdrawals, and to plan for future water needs at the base. Results of the model simulations of the scenarios were used to analyze the effects of the four alternative withdrawal and recharge conditions on the aquifer system.

\section{Model Design}

The existing groundwater-flow model was constructed using the USGS Modular Three-Dimensional FiniteDifference Groundwater- Flow Model (MODFLOW-88) developed by McDonald and Harbaugh (1988). For this study, the model input data was reformatted for a newer version of MODFLOW, MODFLOW-2005 (Harbaugh, 2005), and withdrawals were updated with 2000 to 2010 data. The updated model will be referred to in this report as the 2010 model.

The time intervals simulated in the original model were 1-year stress periods from January 1941 to December 1999. For the 2010 model, the time intervals simulated were years from January 1941 to December 2007, and months from January 2008 to December 2010.

The model grid developed for the original model was used for this study and is shown in figure 4 . The origin of the model grid (the upper left corner of the grid; row 1, column 1) is at an easting of 2,373,237 ft and a northing of $669,380 \mathrm{ft}$ in zone 5 of the California State Plane coordinate system. The grid consists of 80 rows and 64 columns with a cell size of $500 \mathrm{ft}$ on a side (fig. 4).

The MODFLOW code consists of a main program and a series of independent subroutines called modules. The MODFLOW-2005 modules used in the 2010 model include Basic (BAS6); Block-Centered Flow (BCF6); GeneralHead Boundary (GHB); Drain (DRN); Discretization (DIS); Horizontal-Flow-Barrier (HFB6; Hsieh and Freckleton, 1993); Multi-Node Well (MNW2, Konikow and others, 2009); and Recharge (RCH) [BAS6, BCF6, GHB, DRN, and RCH, Harbaugh, 2005, MODFLOW-2005]. The original model (Densmore, 2003) used all of the above-mentioned modules except the MNW2, the WEL module (McDonald and Harbaugh, 1988) was used. For this study, the well input file was reformatted into the format for the MNW2 module. The 2010 model uses the Geometric Multigrid Solver (GMG, Wilson and Naff, 2004), whereas the original model used the Strongly Implicit Procedure Solver (SIP, McDonald and Harbaugh, 1988).

The model representation of the aquifer system, calibrated aquifer properties, and model boundaries simulated in the original model were not changed for this study. The model representation of the aquifer system is shown in figure 5 . Horizontal hydraulic conductivity of the aquifer system ranged from 3 to $25 \mathrm{ft} / \mathrm{d}$ (feet per day) for model layer 1 and 3 to $22 \mathrm{ft} / \mathrm{d}$ for layer 2 . Model boundaries are shown in figure 4 . The lateral boundaries of the model coincide with the lateral boundaries of the aquifer system. The top boundary of the 

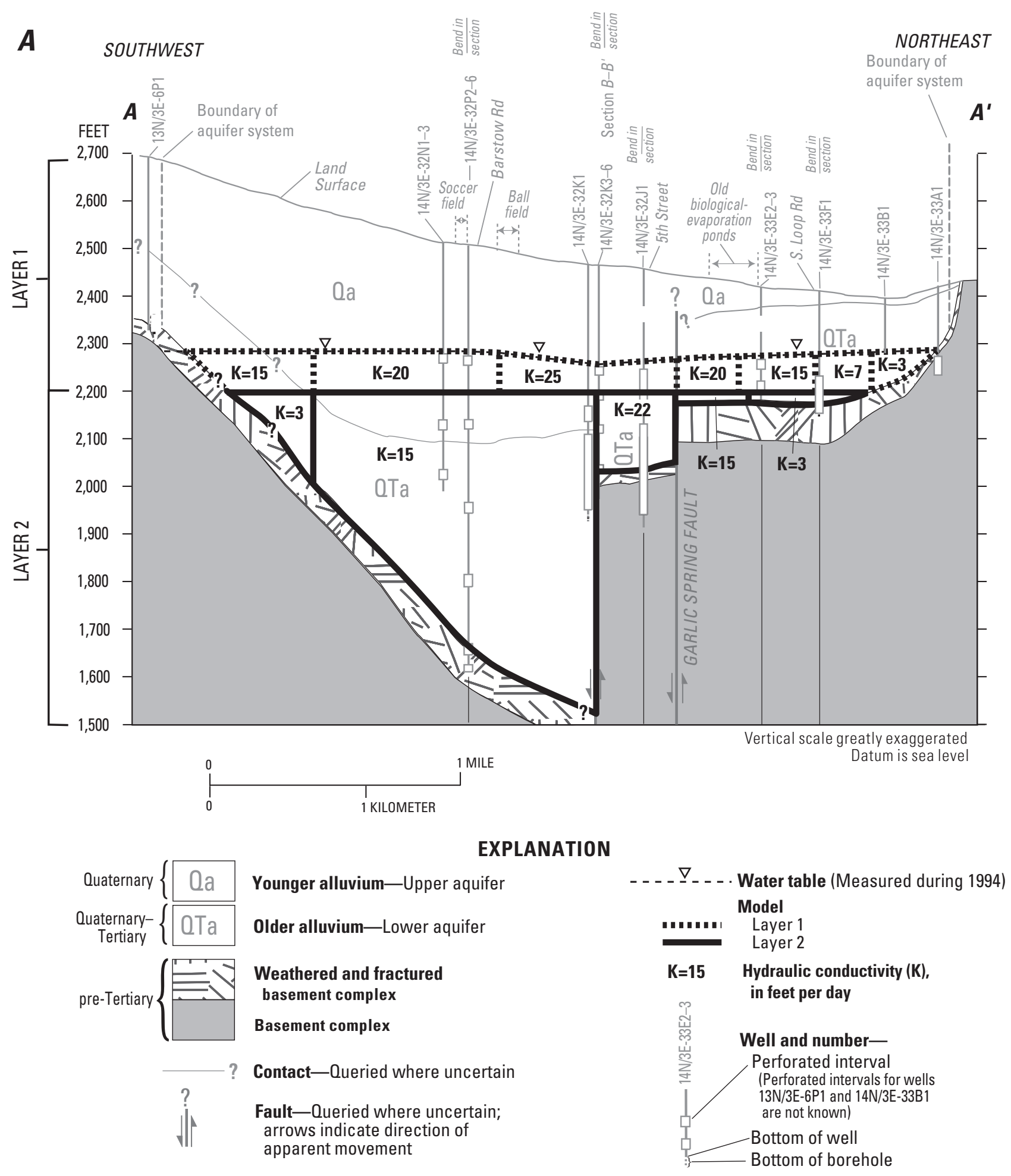

Figure 5. Cross-sectional view of model layers, hydraulic conductivities, and boundary conditions of the Irwin Basin, Fort Irwin National Training Center, California (Densmore, 2003). [Cross-section locations are shown in fig. 2] 
B

B WEST

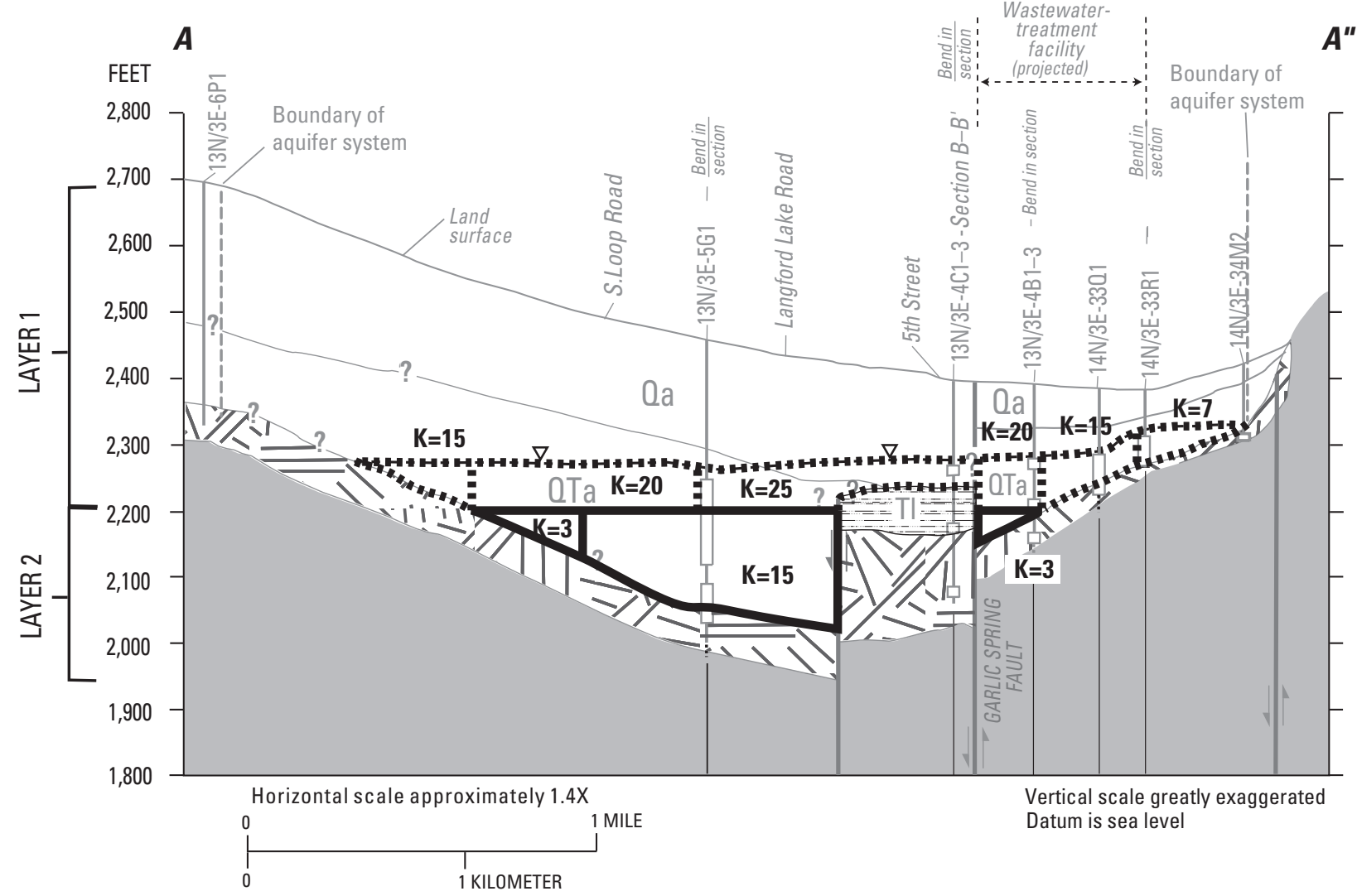

EXPLANATION

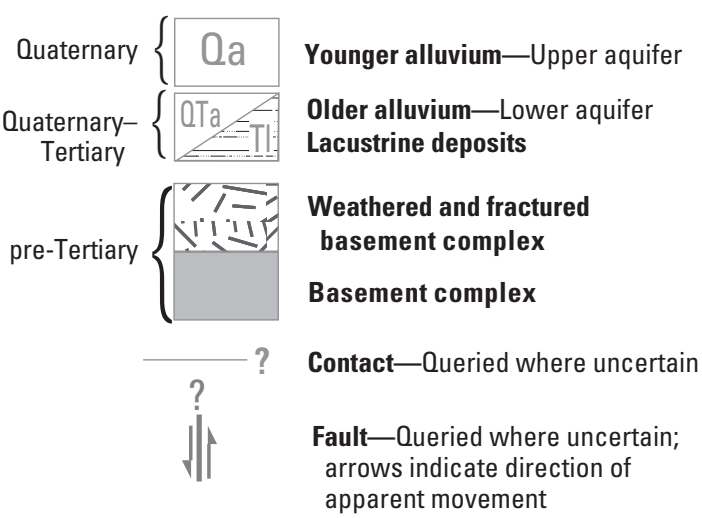

Figure 5. - Continued 


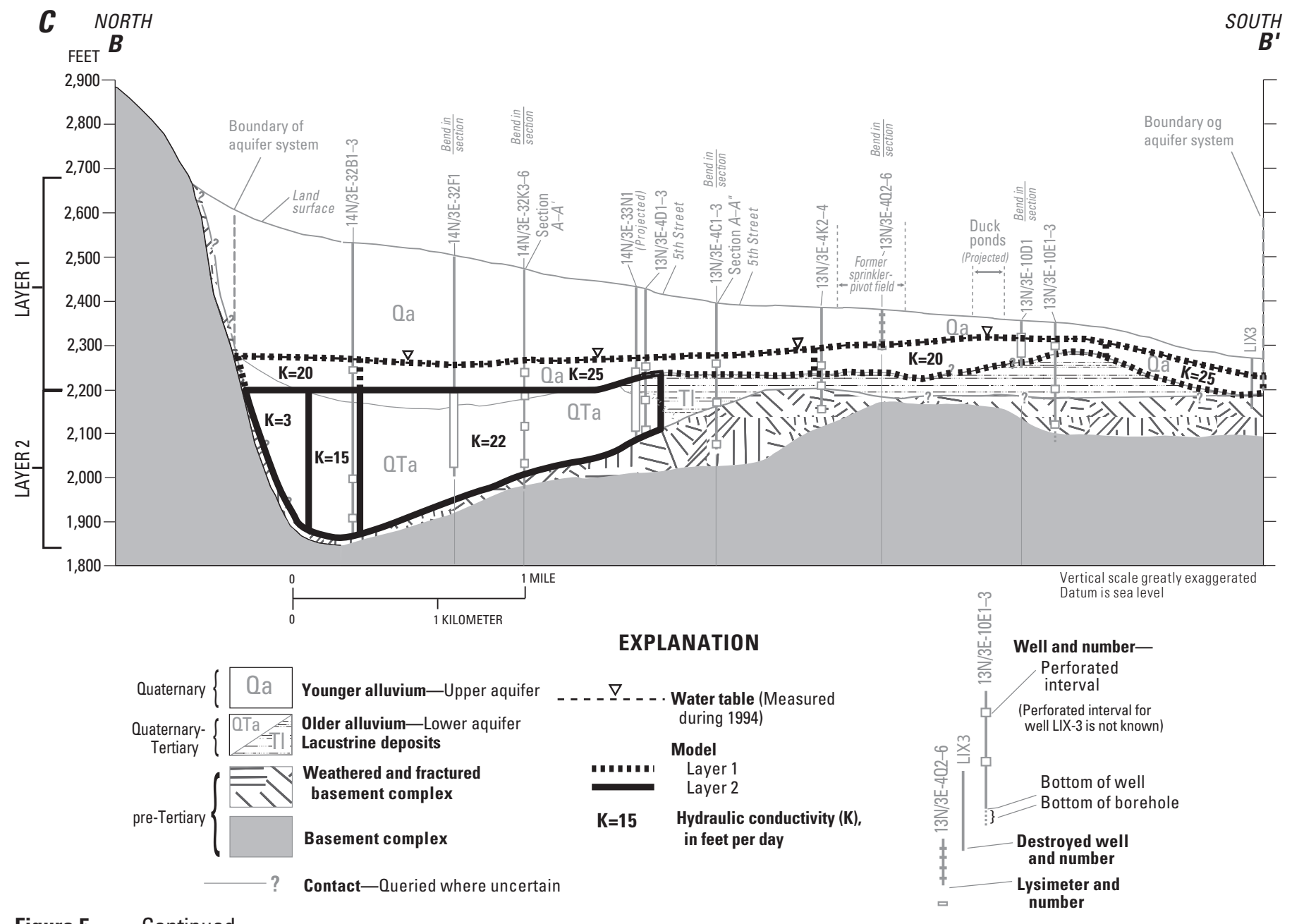

Figure 5. - Continued

model, the water table, is simulated as a free-surface boundary (unconfined) to allow vertical movement in response to changes between inflow and outflow. No-flow boundaries are used around and below the modeled area to represent contact with the basement complex. The HFB6 package was used to simulate the 2 faults that impede the horizontal flow of groundwater. The GHB package was used to simulate underflow from layer 1 through the unnamed wash near Garlic Spring. The reader is referred to Densmore (2003) for a detailed description of the aquifer system framework, aquifer properties and model boundaries.

\section{Model Calibration}

The 2010 model was not re-calibrated, but the results of the simulations made with the original model and the 2010 model were compared to ensure that the original level of calibration was maintained. Simulated 1994 hydraulic heads (or potentiometric surface) from the original model (Densmore, 2003, fig. 19) were compared with those heads simulated in the 2010 model (fig. 6). The comparisons were only visual, however, because the original 1994 hydraulic heads generated by Densmore (2003) were not archived in GIS format. Model budgets calculated for each stress period by MODFLOW in the original and 2010 model were also compared. The original list file, lst.trand114, containing the model budgets, can be requested from the USGS California Water Science Center, San Diego, Calif.

The update of the original model was done in steps to allow for evaluation and analysis of simulation results and to maintain the original level of calibration. First, the original model input data was reformatted from MODFLOW-88 to MODFLOW-2005 format, and then the well input file was reformatted to the newer MNW2 format. The simulated 1994 hydraulic heads, generated from the original model data that had been reformatted to run with MODFLOW-2005, are shown in red in figure 6 and compare well with the original 1994 hydraulic heads generated by Densmore (2003). The MODFLOW-2005 model input data was then run with the original well data reformatted for the MNW2 module. The simulated 1994 hydraulic heads, generated from the 2010 model with the MNW2 well data, are shown in purple in figure 6 and are slightly different in the area of the production wells 14N/3E-32F1, 14N/3E-32H1 and 14N/3E-32K1 (fig. 6) from the hydraulic heads simulated by using the original well data. Using the MNW2 module, the simulated 1994 hydraulic heads for layer 1 at production wells $14 \mathrm{~N} / 3 \mathrm{E}-32 \mathrm{H} 1$ and 

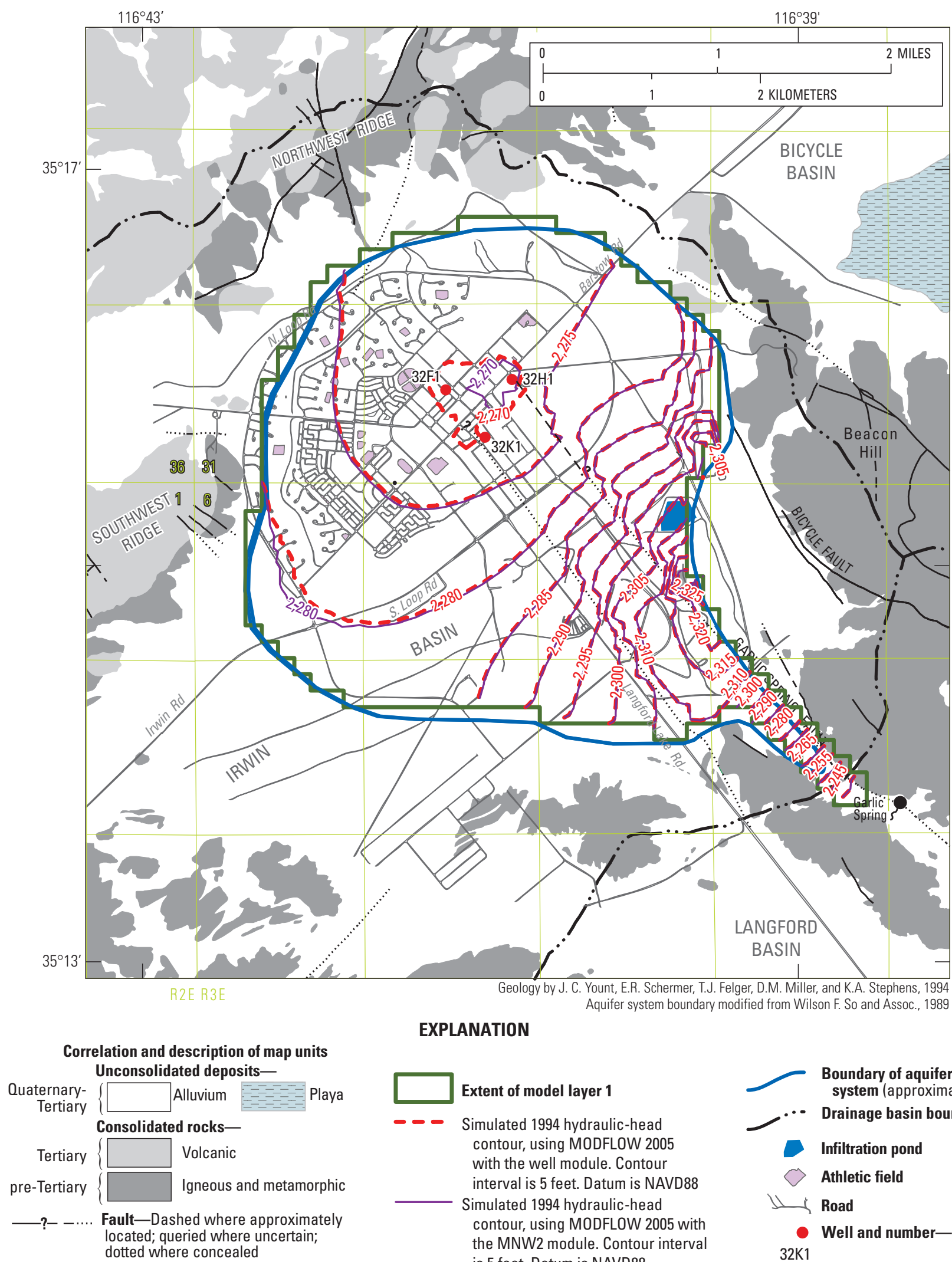

EXPLANATION

Extent of model layer 1

- - Simulated 1994 hydraulic-head contour, using MODFLOW 2005 with the well module. Contour interval is 5 feet. Datum is NAVD88

Simulated 1994 hydraulic-head contour, using MODFLOW 2005 with the MNW2 module. Contour interval is 5 feet. Datum is NAVD88

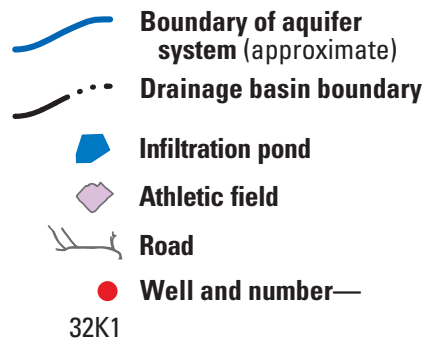

Figure 6. Simulated 1994 hydraulic heads, layer 1, Irwin Basin, Fort Irwin National Training Center, California. 
14N/3E-32K1 are 2.61 and $3.51 \mathrm{ft}$ higher, respectively, than the 1994 simulated hydraulic heads using the WEL module. In contrast, the 1994 hydraulic heads simulated by using the MNW2 module for layer 2 at production wells $14 \mathrm{~N} / 3 \mathrm{E}-32 \mathrm{~F} 1$, $14 \mathrm{~N} / 3 \mathrm{E}-32 \mathrm{H} 1$ and $14 \mathrm{~N} / 3 \mathrm{E}-32 \mathrm{~K} 1$ are $1.28,0.88$ and $1.09 \mathrm{ft}$ lower, respectively, than the 1994 simulated hydraulic heads using the WEL module. With the exception of the hydraulic heads within the closed 2,270-foot contour line (fig. 6), hydraulic heads from both models agree within 0.1 foot. This difference in hydraulic head may be attributed to how the withdrawals were distributed in the original model. The withdrawals from production wells were initially distributed as two-thirds from layer 1 and one-third from layer 2; this initial distribution was then varied between the two layers during calibration in the original model (Densmore, 2003). For the 2010 model, the percentage of groundwater withdrawals from each model layer was calculated by the MNW2 module.

The volumetric model budgets, calculated by MODFLOW, for the original MODFLOW-88 model and the 2010 model for 1994 conditions, which is stress period 54, are shown in table 1. Slight differences in the values for storage and head dependent boundary are probably a result of the difference in the distribution of withdrawals of the production wells calculated by the MNW2 module. Overall, the budget items compare well.

Hydrographs for 11 selected observation wells are shown in figure 7 . Wells were selected on the basis of location and number of water-level measurements available, and only wells screened in a single layer were considered. The measured water levels and simulated hydraulic heads from the 2010 model are within $11 \mathrm{ft}$. Simulated hydraulic heads also matched the upward 1992-2010 trend in measured water levels. The upward trend is probably a result of recharge from the ponds near the wastewater-treatment facility and irrigation at the training center's base housing.

\section{Ground water Withdrawals}

The original model simulated hydrologic conditions from January 1941 to December 1999 with yearly stress periods. In the original model, groundwater withdrawals were averaged for the year. The 2010 model included 2000 to 2010 withdrawal data. Monthly groundwater withdrawal records were available for January 2000 through December 2010. For the 2010 model, groundwater withdrawals were simulated for 1-year periods from January 1941 to December 2007 and for 1-month periods from January 2008 to December 2010. Annual groundwater withdrawals from Bicycle, Irwin, and Langford Basins are shown in figure 8.

\section{Groundwater Recharge}

There are two sources of recharge to the aquifer system in the Irwin Basin: natural recharge from precipitation and artificial recharge from wastewater-effluent infiltration at the ponds and irrigation-return flow (Densmore, 2003). Natural recharge in the basin is low because of low precipitation and high evaporation rates. The calibrated natural recharge simulated in the original model was about $50 \mathrm{acre}-\mathrm{ft} / \mathrm{yr}$. The natural recharge was simulated along the intermittent unnamed wash shown in figure 4 . The natural recharge of 50 acre-ft/yr was used in the 2010 model and simulated in the same model cells as those in the original model that represent the intermittent unnamed wash. Groundwater is imported to the Irwin Basin from Bicycle and Langford Basins. Some water is used for irrigation at the base housing; the water that is not consumed is treated at the wastewater-treatment facility and discharged to the infiltration ponds, referred to as the wastewater treatment facility pond, golf course pond and duck ponds. Estimated groundwater recharge has exceeded groundwater withdrawals

Table 1. Simulated volumetric budget, for 1994 conditions (stress period 54), from the A) original, MODFLOW-88 model and B) 2010 model, Irwin Basin, Fort Irwin National Training Center, California.

[Values in cubic feet per day. Abbreviation: - , none]

\begin{tabular}{|c|c|c|c|}
\hline Budget component & $\begin{array}{l}\text { Original model } \\
\text { (MODFLOW-88) }\end{array}$ & $\begin{array}{c}2010 \text { model } \\
\text { (MODFLOW-2005) }\end{array}$ & $\begin{array}{l}\text { Percent difference between } \\
\text { original and } 2010 \text { model }\end{array}$ \\
\hline \multicolumn{4}{|c|}{ Inflow: } \\
\hline Storage & $6,054.70$ & $5,951.50$ & 0.07 \\
\hline Recharge & $152,271.55$ & $152,271.61$ & -0.00 \\
\hline Total in & $158,330.00$ & $158,223.11$ & - \\
\hline \multicolumn{4}{|c|}{ Outflows: } \\
\hline Storage & $7,627.10$ & $7,517.36$ & 0.07 \\
\hline Groundwater withdrawals & $140,691.00$ & $140,691.00$ & 0.00 \\
\hline Head dependent boundary & $9,998.90$ & $10,015.42$ & -0.01 \\
\hline Total out & $158,320.00$ & $158,223.78$ & - \\
\hline Inflow-outflow & 9.20 & -0.67 & - \\
\hline Percent discrepancy & 0.01 & 0.00 & - \\
\hline
\end{tabular}



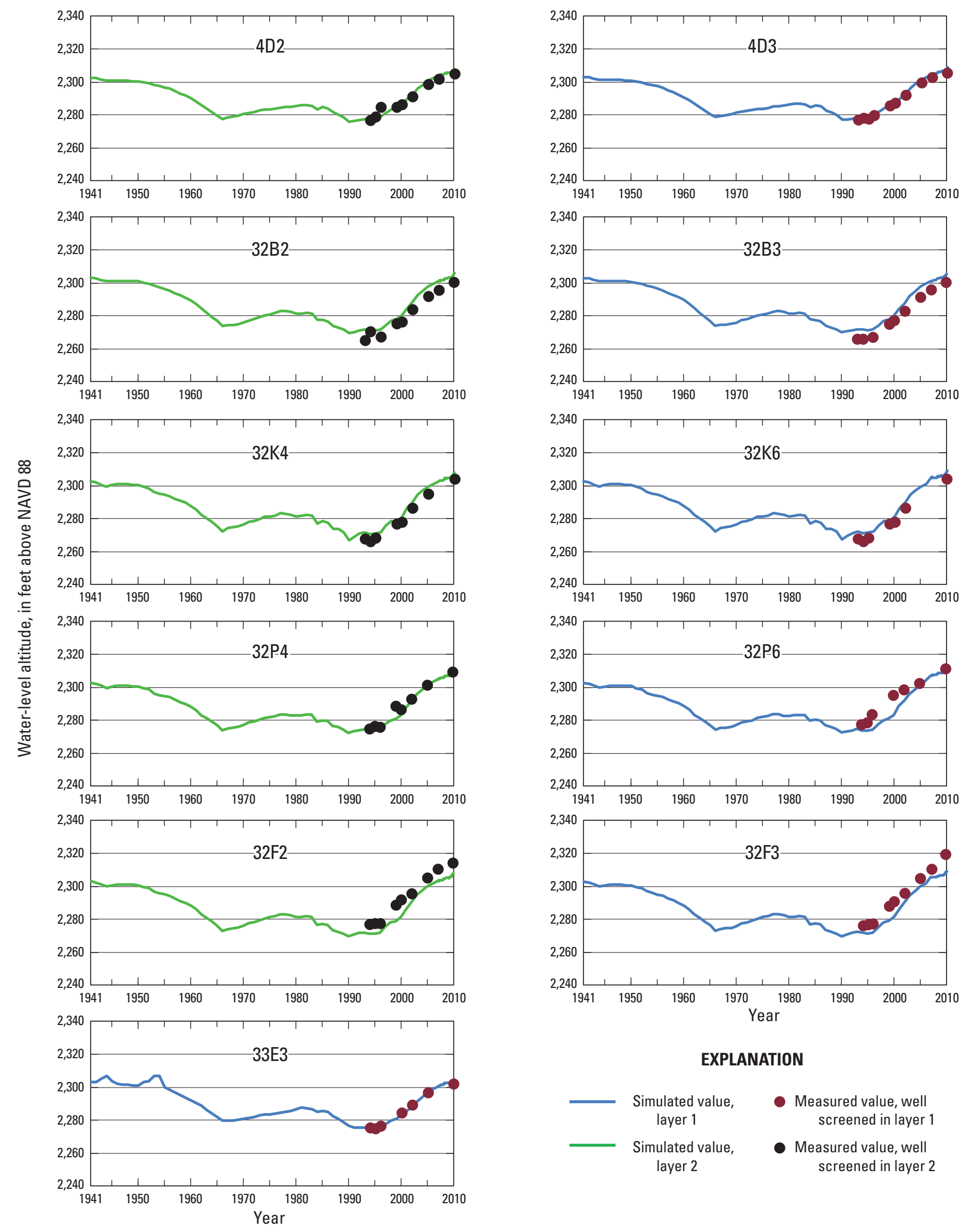

\section{EXPLANATION}

Simulated value, - Measured value, well layer $1 \quad$ screened in layer 1

Simulated value, - Measured value, well layer $2 \quad$ screened in layer 2

Figure 7. Hydrographs of measured water levels and simulated hydraulic heads in 11 observation wells, Irwin Basin, Fort Irwin National Training Center, California. [Well location shown in fig. 11] 


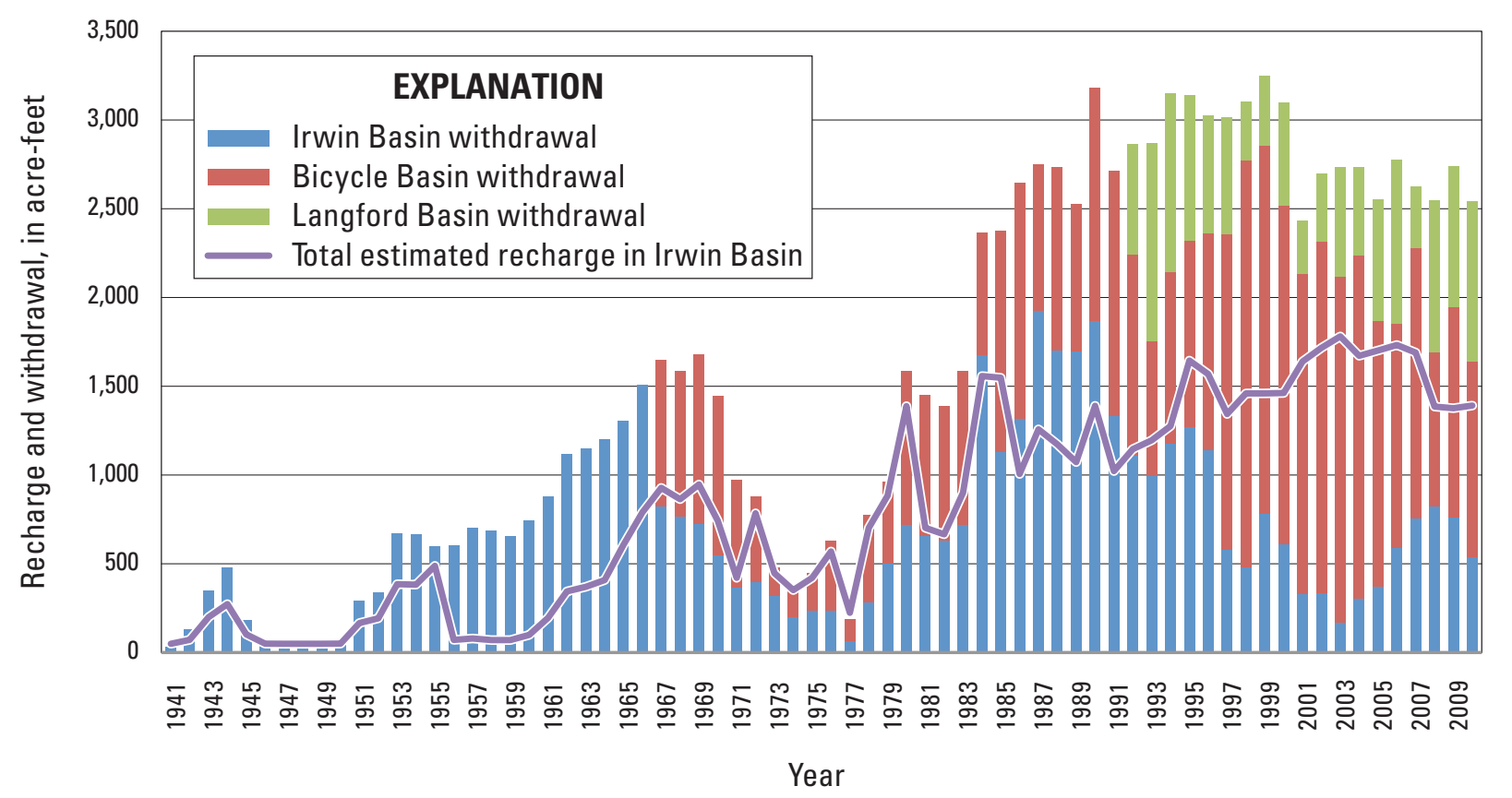

Figure 8. Annual groundwater recharge and withdrawals from Bicycle, Irwin, and Langford Basins, Fort Irwin National Training Center, California, 1941-2010.

in the Irwin Basin since 1967, except for the years 1984 and 1986-91. From 1967, about 33,980 acre-ft was withdrawn from the groundwater-flow system within the Irwin Basin and an estimated 50,600 acre-ft recharged the basin, resulting in a net gain of 16,620 acre-ft of water to the groundwater-flow system (fig. 8 and table 2). Reduced pumping in the Irwin Basin, recharge from irrigation at the base housing, and artificial recharge from treated wastewater at the infiltration ponds has caused water levels to stabilize or rise throughout most of the Irwin Basin (fig. 7).

The recharge rate used in the original model at the recreational fields (soccer, baseball, and Army ball fields) and grass areas at the base housing (fig. 2) was used in the 2010 model for January 2000 to December 2007. Additional base housing (fig. 2) was constructed in phases during May 2005, May 2008, and November 2008. Recharge was simulated in the 2010 model for these areas beginning in 2005. The original model simulated an average yearly recharge rate, in cubic feet per day, from January 1941 to December 1999. The recharge rate simulated in the original model was used in the 2010 model for the monthly stress periods from January 2008 to December 2010. At the recreational fields and grass areas at the base housing, the recharge rate was decreased by half for the winter months, January, February, November and December.
Estimates of daily evaporation and evapotranspiration from studies by the California Department of Water Resources (DWR) and the California Irrigation Management Information System (CIMIS) of DWR's Office of Water Use Efficiency, respectively, were used in the calculation of water available for monthly recharge at the wastewater infiltration ponds (pond locations shown in fig. 2), where outflow from the wastewater-treatment facility is discharged in the Irwin Basin. Using an annual evaporation rate of $5.7 \mathrm{ft}$, the 2010 evaporation from the surface of wastewater infiltration ponds (area of ponds is 47 acres) was estimated to be about 270 acre-ft (table 3). Using an annual evapotranspiration rate of $6 \mathrm{ft}$, the 2010 evapotranspiration from the area (about 40 acres) around the wastewater infiltration ponds was estimated to be 240 acre-ft. There are no data available on the depth to groundwater within $500 \mathrm{ft}$ of the ponds from wells screened within $20 \mathrm{ft}$ of land surface. The well nearest to any of the infiltration ponds (pond locations shown in fig. 2) is observation well 13N/3E-10D1, screened 15 to $65 \mathrm{ft}$ below land surface and located about $500 \mathrm{ft}$ southeast of the southernmost duck pond. The water level in this well was $15 \mathrm{ft}$ below land surface on October 21, 2010. A shallow depth to groundwater was assumed for the area around the ponds because of the vegetation growing there, and the water from the ponds would flow laterally, in addition to vertically, into the surrounding aquifer. A shallow depth to groundwater, less than $10 \mathrm{ft}$, was 
Table 2. Simulated annual 1941-2010 groundwater recharge and withdrawals, Irwin Basin, Fort Irwin National Training Center, California.

[Values in acre-feet per year.]

\begin{tabular}{|c|c|c|c|c|c|}
\hline Year & Withdrawal & Recharge & Year & Withdrawal & Recharge \\
\hline 1941 & 33 & 49 & 1976 & 236 & 569 \\
\hline 1942 & 130 & 71 & 1977 & 64 & 224 \\
\hline 1943 & 350 & 199 & 1978 & 283 & 702 \\
\hline 1945 & 182 & 102 & 1980 & 721 & 1,388 \\
\hline 1946 & 57 & 50 & 1981 & 660 & 702 \\
\hline 1947 & 55 & 49 & 1982 & 630 & 666 \\
\hline 1949 & 55 & 49 & 1984 & 1,675 & 1,558 \\
\hline 1950 & 55 & 50 & 1985 & 1,133 & 1,548 \\
\hline 1951 & 293 & 166 & 1986 & 1,315 & 1,006 \\
\hline 1952 & 336 & 193 & 1987 & 1,927 & 1,257 \\
\hline 1953 & 671 & 385 & 1988 & 1,700 & 1,173 \\
\hline 1954 & 668 & 382 & 1989 & 1,696 & 1,073 \\
\hline 1958 & 686 & 70 & 1993 & 997 & 1,196 \\
\hline 1959 & 655 & 70 & 1994 & 1,180 & 1,276 \\
\hline 1960 & 746 & 99 & 1995 & 1,270 & 1,645 \\
\hline 1961 & 881 & 195 & 1996 & 1,138 & 1,568 \\
\hline 1962 & 1,119 & 344 & 1997 & 580 & 1,343 \\
\hline 1963 & 1,147 & 370 & 1998 & 484 & 1,460 \\
\hline 1964 & 1,202 & 408 & 1999 & 781 & 1,460 \\
\hline 1965 & 1,305 & 607 & 2000 & 612 & 1,462 \\
\hline 1966 & 1,509 & 790 & 2001 & 331 & 1,640 \\
\hline 1967 & 827 & 928 & 2002 & 333 & 1,716 \\
\hline 1968 & 764 & 864 & 2003 & 168 & 1,781 \\
\hline 1969 & 727 & 947 & 2004 & 301 & 1,671 \\
\hline
\end{tabular}




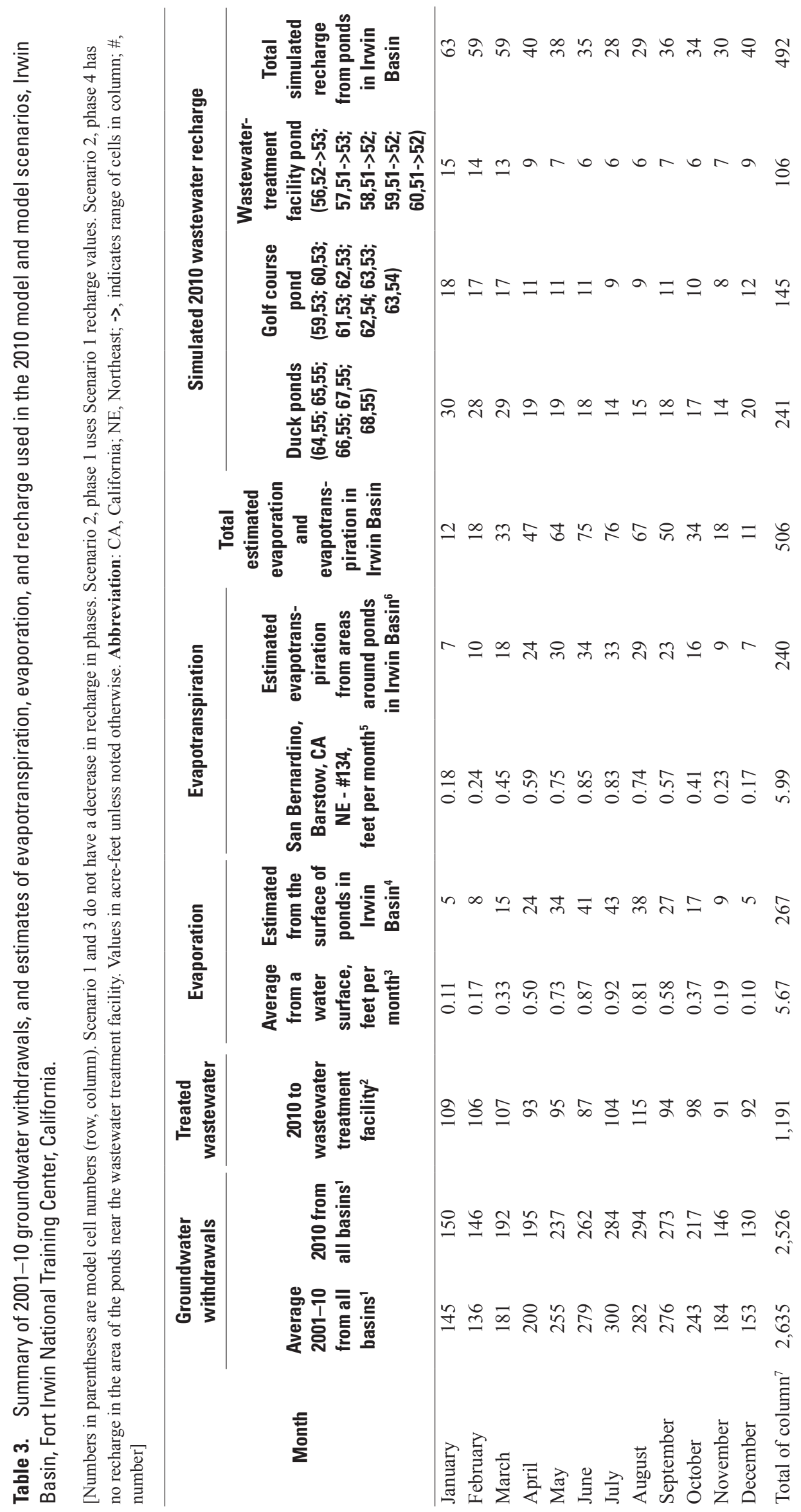




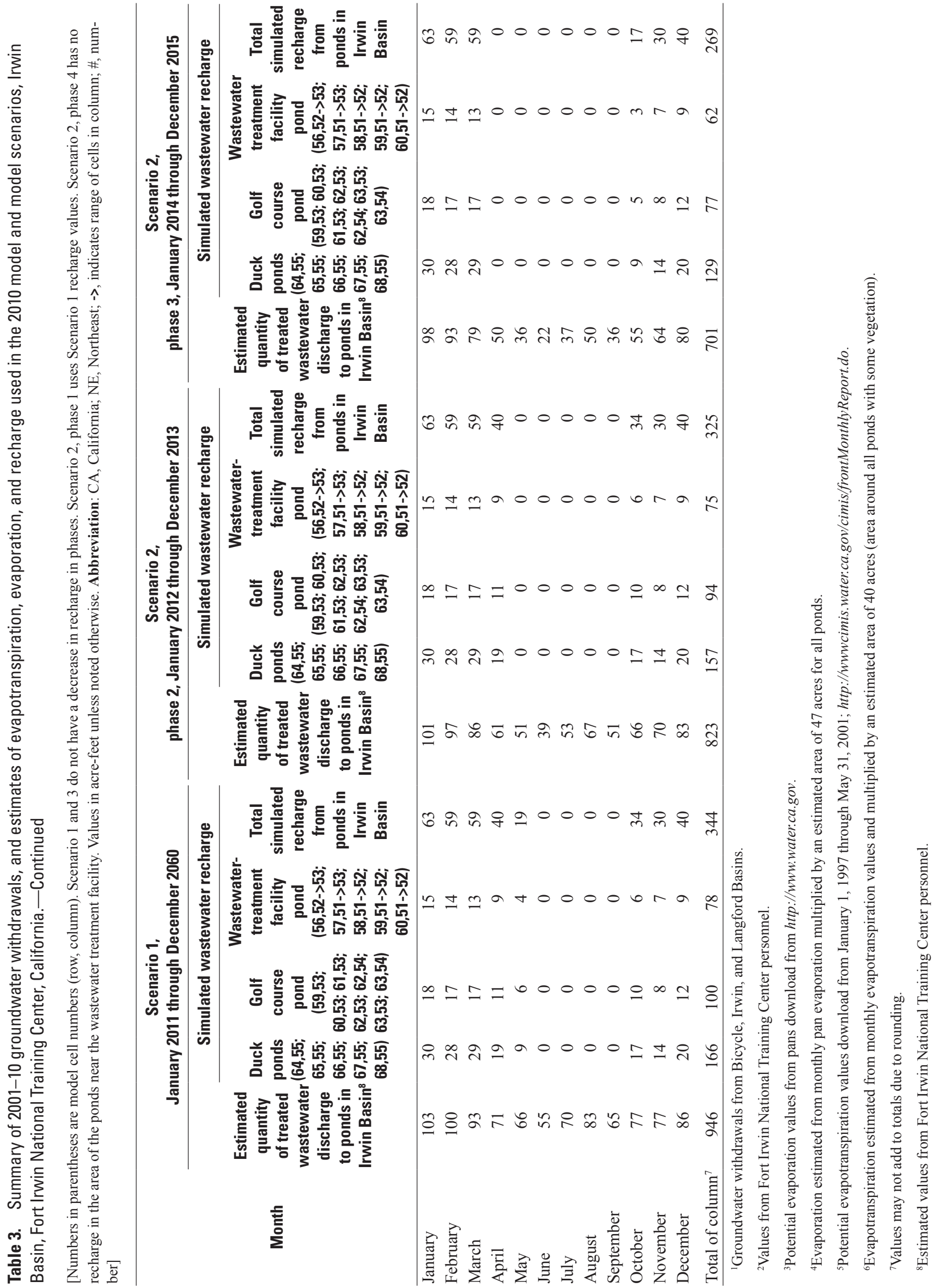


assumed for a radial distance of $250 \mathrm{ft}$ from the edge of the wastewater infiltration ponds and evapotranspiration would occur over 40 acres around the ponds. Evapotranspiration would decrease the water available for groundwater recharge to the aquifer system. Simulated annual 1941 to 1999 recharge in the original model ranges from 49 to $1,644 \mathrm{acre}-\mathrm{ft} / \mathrm{yr}$ (fig. 8). Simulated annual 2000 to 2010 recharge in the updated 2010 model ranges from 1,462 to 1,781 acre-ft/yr (fig. 8).

Periodic water-level measurements by USGS personnel at six observation wells (13N/3E-4B3, -4G1, 4K1,-4K4, $-4 \mathrm{Q} 4$, and $-10 \mathrm{D} 1)$ near the wastewater-treatment facility were compared to simulated hydraulic heads to insure the calculated 2008-10 monthly recharge rates did not have an adverse effect on model calibration. The observation wells are screened in model layer 1 . The measured water levels and simulated hydraulic heads, which are within 1-20 ft, at the six observation wells (fig. 9). The larger differences between simulated and measured values may be due, in part, to inaccuracies in the distribution of pumpage to the individual wells during 1999 and 2004 and an inaccurate estimation of the quantity and distribution of artificial recharge.

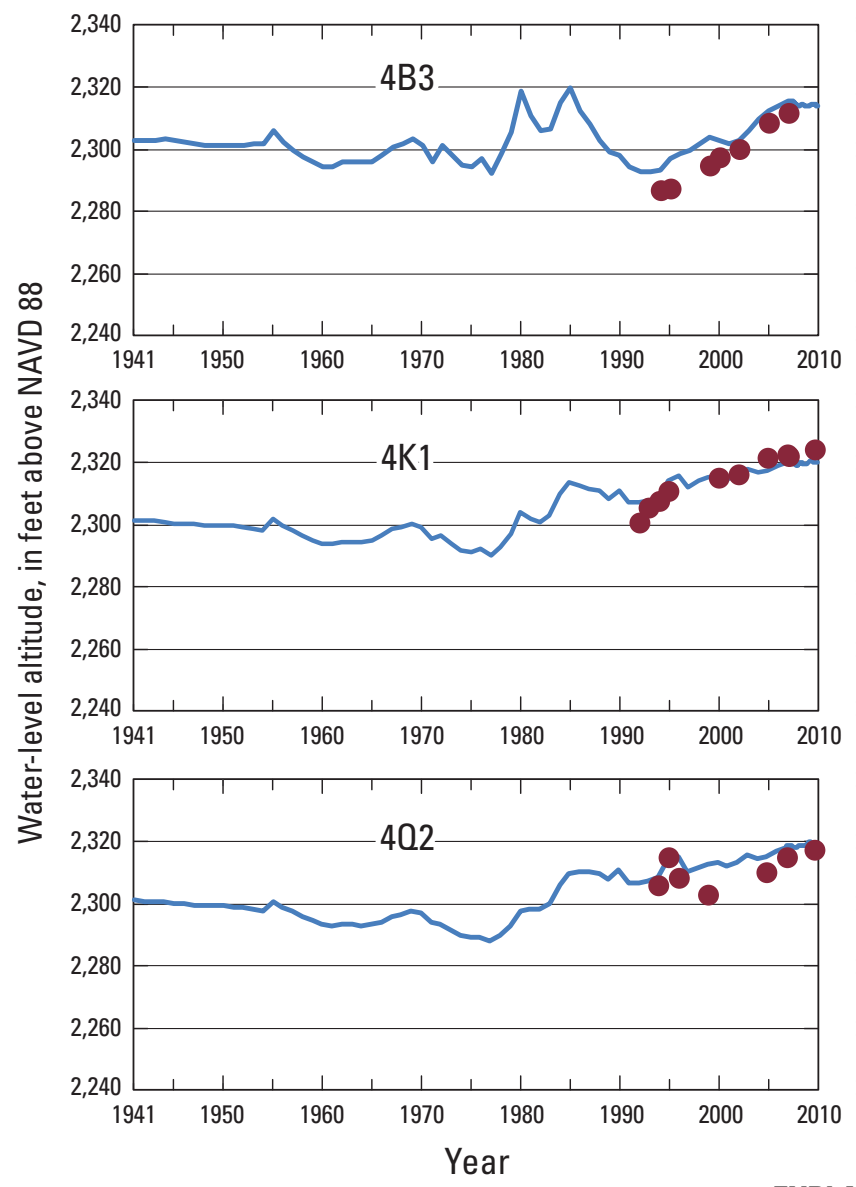

\section{Simulated Effects of Future Withdrawals and Artificial Recharge}

The updated 2010 model was used to assess the possible effect of four groundwater withdrawal and artificial recharge scenarios on the groundwater-flow system within the Irwin Basin. These four scenarios were developed in cooperation with Fort Irwin National Training Center personnel and used to simulate conditions from January 2011 to December 2060. All of the model scenarios use the simulated December 2010 hydraulic heads as initial conditions. Monthly values for proposed withdrawals and estimated artificial recharge were simulated for January 2011 through December 2060.

For the scenarios, the drain module was added to simulate groundwater discharge in areas where water levels rise above land surface because of groundwater recharge simulated in those areas. Groundwater levels rise above land surface in the southern area of the Irwin Basin where the land surface is topographically low, around 2,340 NAVD88, and are described in more detail in the Results of Simulations sections.
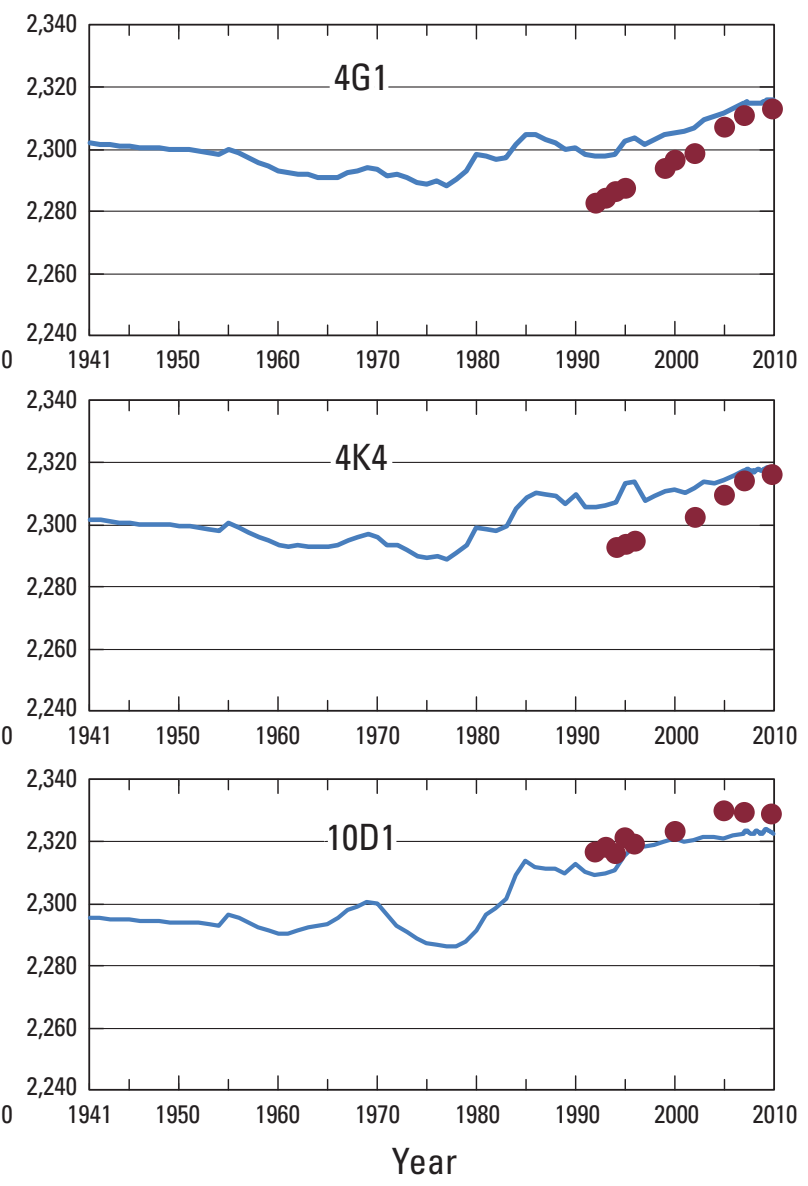

EXPLANATION

— Simulated value, layer 1 Measured value, well screened in layer 1

Figure 9. Hydrographs of measured water levels and simulated hydraulic heads in six observation wells near the wastewatertreatment facility, Irwin Basin, Fort Irwin National Training Center, California. [Well locations shown in fig. 11] 


\section{Description of Model Scenarios}

Artificial groundwater recharge simulated for each of the model scenarios was adjusted in the area of the ponds near the wastewater-treatment facility, based on estimates by Fort Irwin personnel of the quantity of wastewater that may be discharged to the ponds in the future. The quantity of treated wastewater discharged to the ponds is anticipated to be reduced as a result of plans to use the wastewater, rather than "newly pumped" groundwater, for irrigation. Groundwater withdrawals also were adjusted for each of the scenarios to represent the redistribution or reduction of estimated amounts that are anticipated by Fort Irwin personnel. Simulated groundwater withdrawals and artificial recharge for each scenario are described below.

\section{Scenario 1}

Scenario 1 simulates the 2010 annual rate of withdrawals (536 acre-ft/yr) from production well 14N/3E-32H1 in the Irwin Basin (table 4) and remains constant from 2011 to 2060. The monthly distribution of withdrawals (fig. 10) was estimated as a percentage from the monthly withdrawals from all production wells in the Irwin, Bicycle, and Langford Basins for the 10-year period, 2001 through 2010 in order to reflect the monthly groundwater requirement needed by operations at the Fort Irwin NTC. The monthly groundwater withdrawals for the Irwin Basin were calculated by multiplying the 2010 total groundwater withdrawals ( $536 \mathrm{acre}-\mathrm{ft} / \mathrm{yr}$ ) from production well 14N/3E-32H1 by the percentage for a particular month. The monthly withdrawals used in scenario 1 ranged from 27 to 61 acre-ft (table 4).

The estimated quantity of treated wastewater discharged to the infiltration ponds near the wastewater-treatment facility (pond locations shown in fig. 2) for 2011 through 2060 was reduced from the 2010 values. The quantity of treated wastewater discharged to the ponds ranges from 55 to 103 acre-ft/month (table 3) for scenario 1. Because less treated wastewater will be discharged to the ponds, less water will be available for recharge. If the quantity of treated wastewater discharged to the ponds exceeded the total of the evaporation and evapotranspiration rate and was greater than the 2010 monthly recharge rate from the ponds, then the 2010 recharge rate from wastewater shown in table 3 was simulated for that month. If the quantity of treated wastewater discharged to the ponds was less than the total of the evaporation and evapotranspiration rate and there was wastewater left over from the previous month, then the simulated 2010 recharge rate from wastewater was decreased for that month. If the quantity of treated wastewater discharged to the ponds was less than the total of the evaporation and evapotranspiration rate and there was no wastewater left over from the previous month, then the simulated 2010 recharge rate is zero. The monthly recharge rate in the area of the ponds calculated from the quantity of treated wastewater in the ponds ranged from 0 to 63 acre-ft/month (table 3).

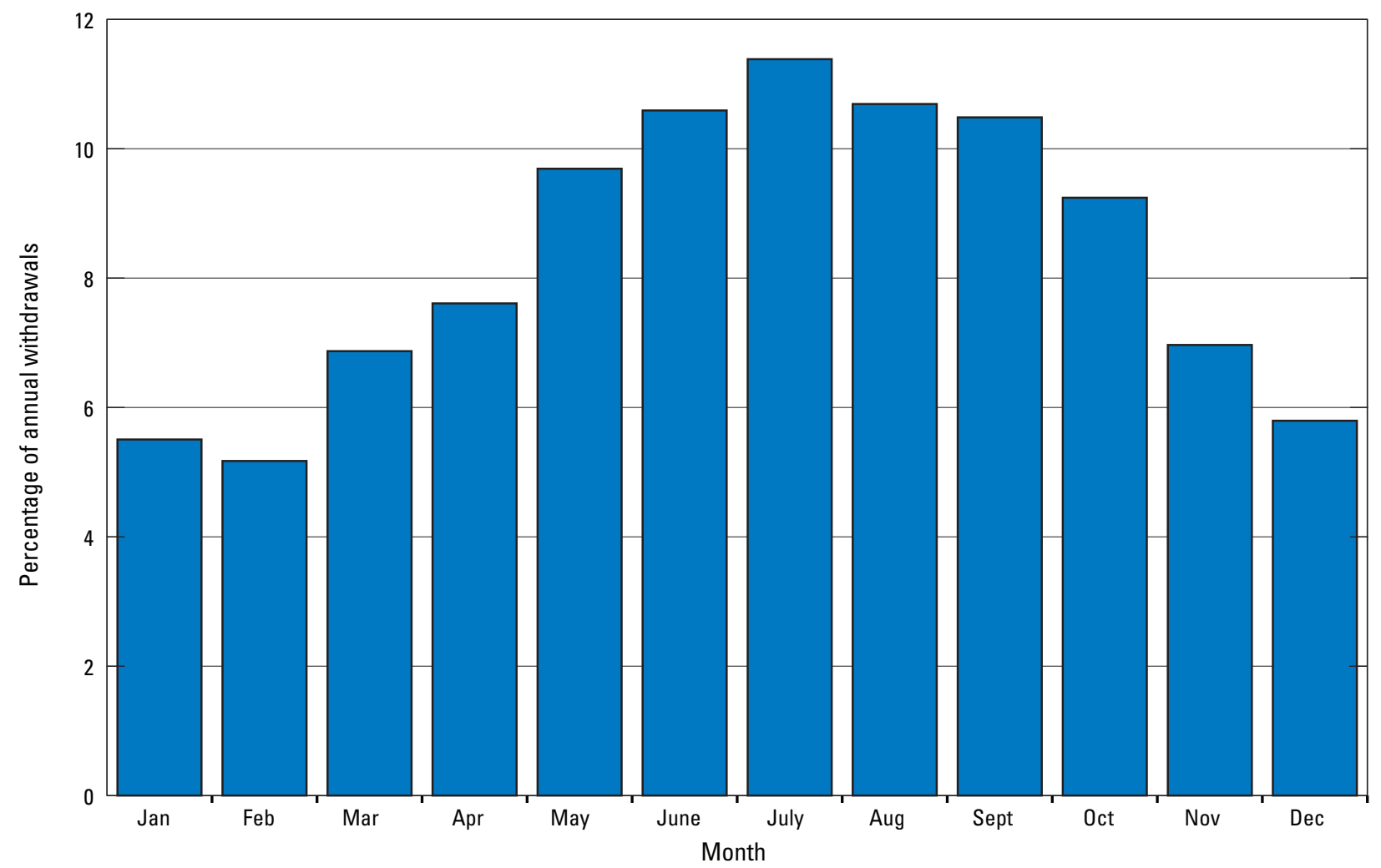

Figure 10. Average 2001 to 2010 total monthly groundwater withdrawal distribution for wells in the Bicycle, Irwin, and Langford Basins that were used to provide water to Fort Irwin National Training Center, California. 
Table 4. Summary of simulated monthly groundwater withdrawals from wells in the Irwin Basin used in the four scenarios, Irwin Basin, Fort Irwin National Training Center, California.

[Values in acre-feet. 14N/3E-32M1 (I-2A), 14N/3E-32H1(I-7), 13N/3E-5G2 (I-9), State well number and local well number in parentheses.]

\begin{tabular}{|c|c|c|c|c|c|c|c|c|}
\hline \multirow{2}{*}{ Month } & \multirow{2}{*}{$\begin{array}{c}\text { Scenario } 1 \\
\begin{array}{c}\text { 14N/3E-32H1 } \\
\text { (I-7) }\end{array}\end{array}$} & \multicolumn{3}{|c|}{ Scenario 2} & \multirow{2}{*}{$\begin{array}{c}2 \text { Scenario } 3 \text {, } \\
30 \text { percent } \\
\text { reduced } \\
\text { withdrawals } \\
\begin{array}{c}14 \mathrm{~N} / 3 \mathrm{E}-32 \mathrm{H} 1 \\
(\mathrm{I}-7)\end{array}\end{array}$} & \multicolumn{3}{|c|}{$\begin{array}{l}{ }^{2} \text { Scenario } 4 \text {, } \\
30 \text { percent reduced withdrawals }\end{array}$} \\
\hline & & $\begin{array}{c}\text { 14N/3E-32H1 } \\
(I-7)\end{array}$ & $\begin{array}{c}13 N / 3 E-5 G 2 \\
(I-9)\end{array}$ & $\begin{array}{l}\text { 114N/3E-32M1 } \\
(\mathrm{I}-2 \mathrm{~A})\end{array}$ & & $\begin{array}{c}\text { 14N/3E-32H1 } \\
(\mathrm{I}-7)\end{array}$ & $\begin{array}{c}13 N / 3 E-5 G 2 \\
(I-9)\end{array}$ & $\begin{array}{l}{ }^{3} 14 \mathrm{~N} / 3 \mathrm{E}-32 \mathrm{M} 1 \\
\quad(\mathrm{I}-2 \mathrm{~A})\end{array}$ \\
\hline January & 30 & 20 & 10 & 0 & 21 & 14 & 7 & 0 \\
\hline Febuary & 27 & 18 & 9 & 0 & 19 & 13 & 6 & 0 \\
\hline March & 37 & 25 & 12 & 3 & 26 & 17 & 9 & 3 \\
\hline April & 41 & 27 & 13 & 10 & 29 & 19 & 9 & 10 \\
\hline May & 52 & 35 & 17 & 12 & 36 & 24 & 12 & 12 \\
\hline June & 57 & 38 & 19 & 6 & 40 & 27 & 13 & 6 \\
\hline July & 61 & 41 & 20 & 0 & 43 & 29 & 14 & 0 \\
\hline August & 57 & 38 & 19 & 0 & 40 & 27 & 13 & 0 \\
\hline September & 56 & 38 & 19 & 0 & 39 & 26 & 13 & 0 \\
\hline October & 50 & 33 & 16 & 0 & 35 & 23 & 11 & 0 \\
\hline November & 37 & 25 & 12 & 0 & 26 & 18 & 9 & 0 \\
\hline December & 31 & 21 & 10 & 0 & 22 & 15 & 7 & 0 \\
\hline Total & 536 & 359 & 177 & 31 & 375 & 251 & 124 & 31 \\
\hline
\end{tabular}

${ }^{1}$ Simulated withdrawals begin in March 2016.

${ }^{2}$ Simulated withdrawals are reduced 3 percent per year for 10 years, from January 2011 to December 20, then the 30 percent reduced withdrawals are simulated January 2021 through December 2060.

${ }^{3}$ No reduction in simulated withdrawals.

\section{Scenario 2}

Scenario 2 simulates the 2010 groundwater withdrawals from production wells $14 \mathrm{~N} / 3 \mathrm{E}-32 \mathrm{M} 1,-32 \mathrm{H} 1$ and 13N/3E-5G2 (well locations shown in fig. 11). Currently (2010), production wells $14 \mathrm{~N} / 3 \mathrm{E}-32 \mathrm{M} 1$ and $13 \mathrm{~N} / 3 \mathrm{E}-5 \mathrm{G} 2$ are inactive. The simulated monthly groundwater withdrawals calculated for scenario 1 were redistributed among production wells $14 \mathrm{~N} / 3 \mathrm{E}-32 \mathrm{H} 1$ (33 percent) and -5G2 (67 percent) during 2010-16 (table 4); groundwater withdrawals from well 14N/3E-32M1 were zero until 2016 based on future seasonal water supply demand anticipated by Fort Irwin personnel. Beginning in March 2016 and continuing until December 2060, simulated withdrawals from production well 14N/3E-32M1 for March, April, May, and June were 3, 10, 12 , and 6 acre-ft/month, respectively, and zero for all other months. The withdrawals from 14N/3E-32M1 are in addition to the withdrawals from production wells $14 \mathrm{~N} / 3 \mathrm{E}-32 \mathrm{H} 1$ and $-5 \mathrm{G} 2$.

For Scenario 2, the estimated quantity of treated wastewater discharged to the infiltration ponds was reduced in four phases from the quantity of treated wastewater in 2010 (table 3). The quantity of treated wastewater discharged to the infiltration ponds for scenario 2, phase 1, (January 2011 through December 2011) used the same values calculated for scenario 1 (January 2011 through December 2060) and ranged from 55 to $103 \mathrm{acre}-\mathrm{ft} / \mathrm{month}$. The simulated quantity of treated wastewater discharged to the infiltration ponds ranged from 39 to 101 acre-ft/month for phase 2, (January 2012 through December 2013), 22 to 98 acre-ft/month for phase 3, (January 2014 through December 2015) and no discharge to the infiltration ponds for phase 4, (January 2016 through December 2060).

The calculated monthly recharge rates in the area of the ponds for phase 2 and 3 of scenario 2 ranged from 0 to 63 acre-ft/month (table 3 ). The calculated monthly recharge was zero in the model for phase 4 in the area of the ponds. The treated wastewater for phase 4 is assumed to be used for irrigation (currently (2010) supplied by groundwater) and cooling towers and any remaining wastewater will be discharged to a proposed 2-mile-long drainage ditch. The 1,400 acre-ft/yr of water used for irrigation (1,200 acre-ft/yr ) and cooling towers (200 acre-ft/yr), however, exceeds the quantity of water treated at the wastewater treatment facility, 1,190 acre-ft/yr. Hence, there will be no wastewater available to discharge to the proposed drainage ditch at the base. 


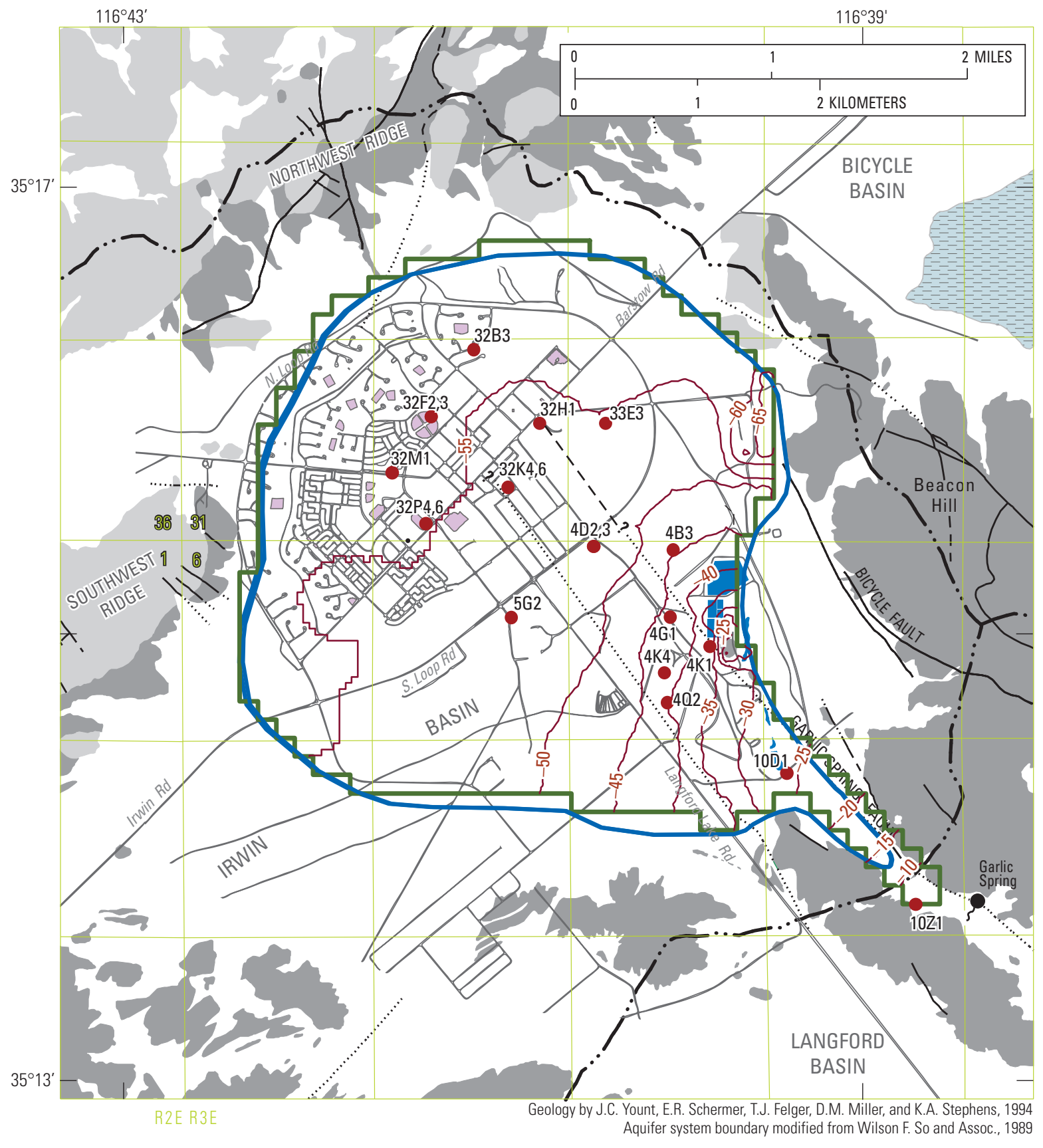

Correlation and description of map units Unconsolidated deposits-

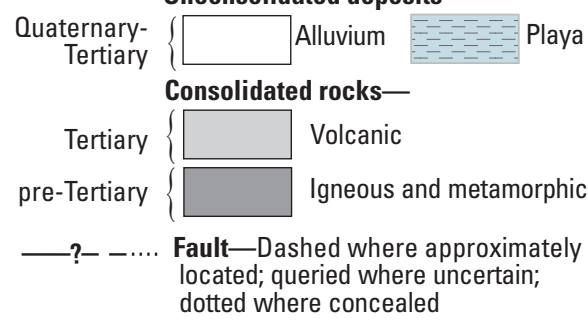

\section{EXPLANATION}

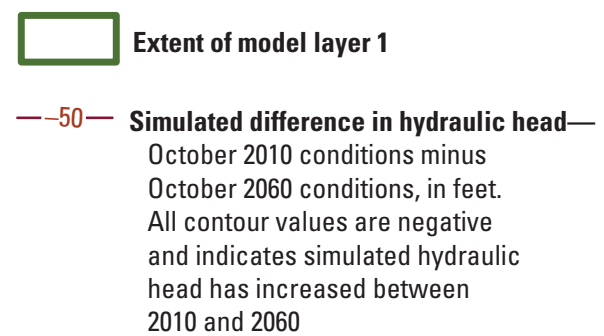

Figure 11. Simulated difference in hydraulic head from October 2010 conditions to 0 ctober 2060 conditions, scenario 1, layer 1, Irwin Basin, Fort Irwin National Training Center, California. 


\section{Scenario 3}

Scenario 3 simulates a 3 percent per year reduction in the 2010 withdrawal rate for 10 years, from January 2011 through December 2020. The 30 percent reduction in withdrawal rate (from the initial 2010 rate) was then applied in the simulation from January 2021 until December 2060 (table 4). The withdrawals are simulated from production well 14N/3E-32H1 (I-7). The same quantity of treated wastewater discharged to the ponds near the wastewater-treatment facility for scenario 1 was used in scenario 3 (table 3 ). In addition, the same recharge rate simulated in the area of the ponds in scenario 1 was used in scenario 3 .

\section{Scenario 4}

Scenario 4 simulates the same distribution of withdrawals among the production wells as scenario 2 , but reduces the 2010 withdrawals 3 percent per year for 10 years (January 2011 through 2020) at wells 14N/3E-32H1 and $13 \mathrm{~N} / 3 \mathrm{E}-5 \mathrm{G} 2$. As in scenario 3, the 30 percent reduction in withdrawal rates (from the initial 2010 rate) was then simulated from January 2021 until December 2060 (table 4). Withdrawals at well14N/3E-32M1 were not reduced. Similar to scenario 2 , the estimated quantity of treated water discharged to the ponds near the wastewater treatment facility and the simulated recharge rate were varied in 4 phases beginning in January 2011, January 2012, January 2014, and January 2016 , and are shown in table 3 . The same quantity of treated wastewater discharged to the ponds near the wastewater-treatment facility for scenario 2 was used in scenario 4 . The same recharge rate simulated in the area of the ponds for scenario 2 was used in scenario 4.

\section{Results of Simulations}

Results of the simulations of the four scenarios are presented as maps of the difference in hydraulic heads from October 2010 to October 2060 for model layer 1. (figs. 11-14). The head values for October are assumed to represent water levels after the high groundwater withdrawal rates during the summer. A negative value for the change in hydraulic head indicates the simulated hydraulic head has increased between 2010 and 2060.
Hydrographs showing the simulated hydraulic heads for each of the four scenarios from 2011 to 2060 at 14 well locations are presented in figure 15 . Water levels in production wells $14 \mathrm{~N} / 3 \mathrm{E}-32 \mathrm{M} 1$ (I-2A), -32H1 (I-7) and $13 \mathrm{~N} / 3 \mathrm{E}-5 \mathrm{G} 2$ (I-9) are representative of conditions in a cone of depression that may form in response to groundwater withdrawals. The aquifer response in the area of a cone of depression to changes in recharge will be most evident in the hydrographs of production wells. The water levels in observation wells 13N/3E-4D3, -4G1, -4K1, -4K4, -4Q2, $-10 \mathrm{D} 1,14 \mathrm{~N} / 3 \mathrm{E}-32 \mathrm{~B} 3,-32 \mathrm{~F} 3,-32 \mathrm{~K} 6,-32 \mathrm{P} 6$, and $-33 \mathrm{E} 3$ are representative of groundwater conditions in the Irwin Basin. The changes in simulated hydraulic heads at the 14 wells are summarized in table 5 .

\section{Scenario 1}

In scenario 1, the 2010 annual rate of withdrawals (536 acre-ft/yr) was held constant from 2011 to 2060, for a cumulative withdrawal of 26,800 acre-ft. Continuation of the 2010 withdrawal rate and recharge from irrigation at the base housing, and a decrease in the recharge at the ponds, resulted in an increase in groundwater levels throughout Irwin Basin. These increases were as much as $55 \mathrm{ft}$ in the area underlying the base housing in the northwestern part of the basin and $10 \mathrm{ft}$ in the southeastern area near the unnamed wash exiting the basin (fig. 11 and table 5). The rise in water levels in the northwestern part of the basin is a result of continued recharge from irrigation at the base housing. Even though there is a simulated decrease in recharge at the ponds, simulated groundwater levels continue to rise in the area of the ponds. Analysis of simulation results indicate groundwater levels rose to land surface around the golf course pond, duck ponds and well 13N/3E-10D1. Simulated groundwater discharge to the drains, which was simulated around the golf course pond, duck ponds and the unnamed wash near well 13N/3E-10D1, ranges from 1 to 205 acre-ft/year by 2060 (table 6). Beginning in March 2044, simulated hydraulic heads rise to land surface at well 13N/3E-10D1 (2,345 ft above sea level [NAVD 88] intermittently during the year (fig. 15). Prior to March 2044, simulated hydraulic heads remain below land surface. The altitude of land surface ranges from 2,344ft above sea level [NAVD 88] at well 13N/3E-10D1 to 2,310 ft above sea level [NAVD 88] at well 13N/3E-10Z1. Simulated groundwater levels remained below land surface north and west of the wastewater treatment plant. 

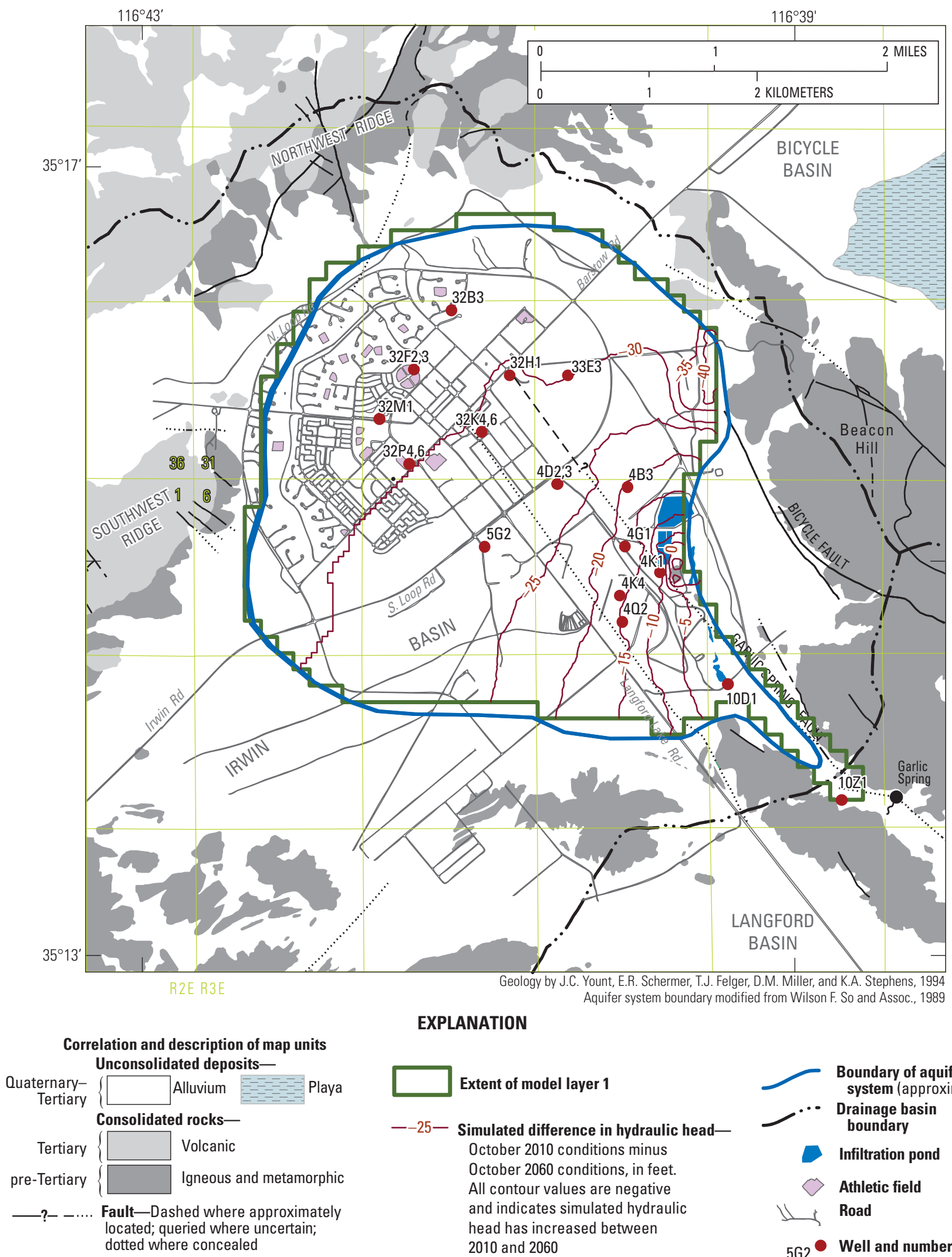

EXPLANATION
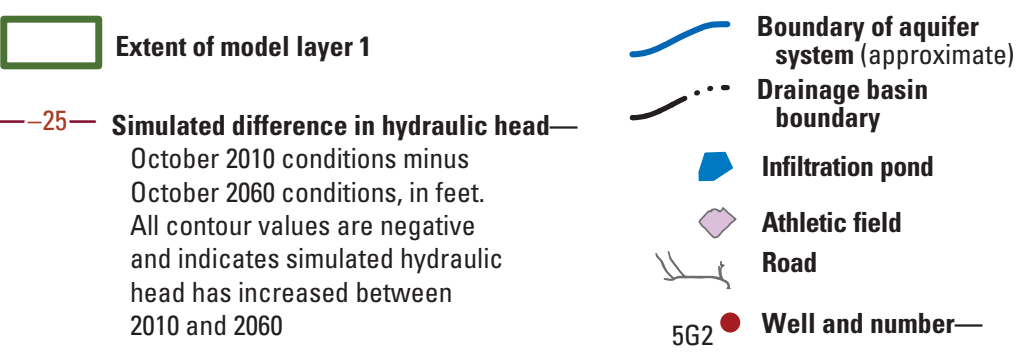

Figure 12. Simulated difference in hydraulic head from October 2010 conditions to 0 ctober 2060 conditions, scenario 2, layer 1, Irwin Basin, Fort Irwin National Training Center, California. 

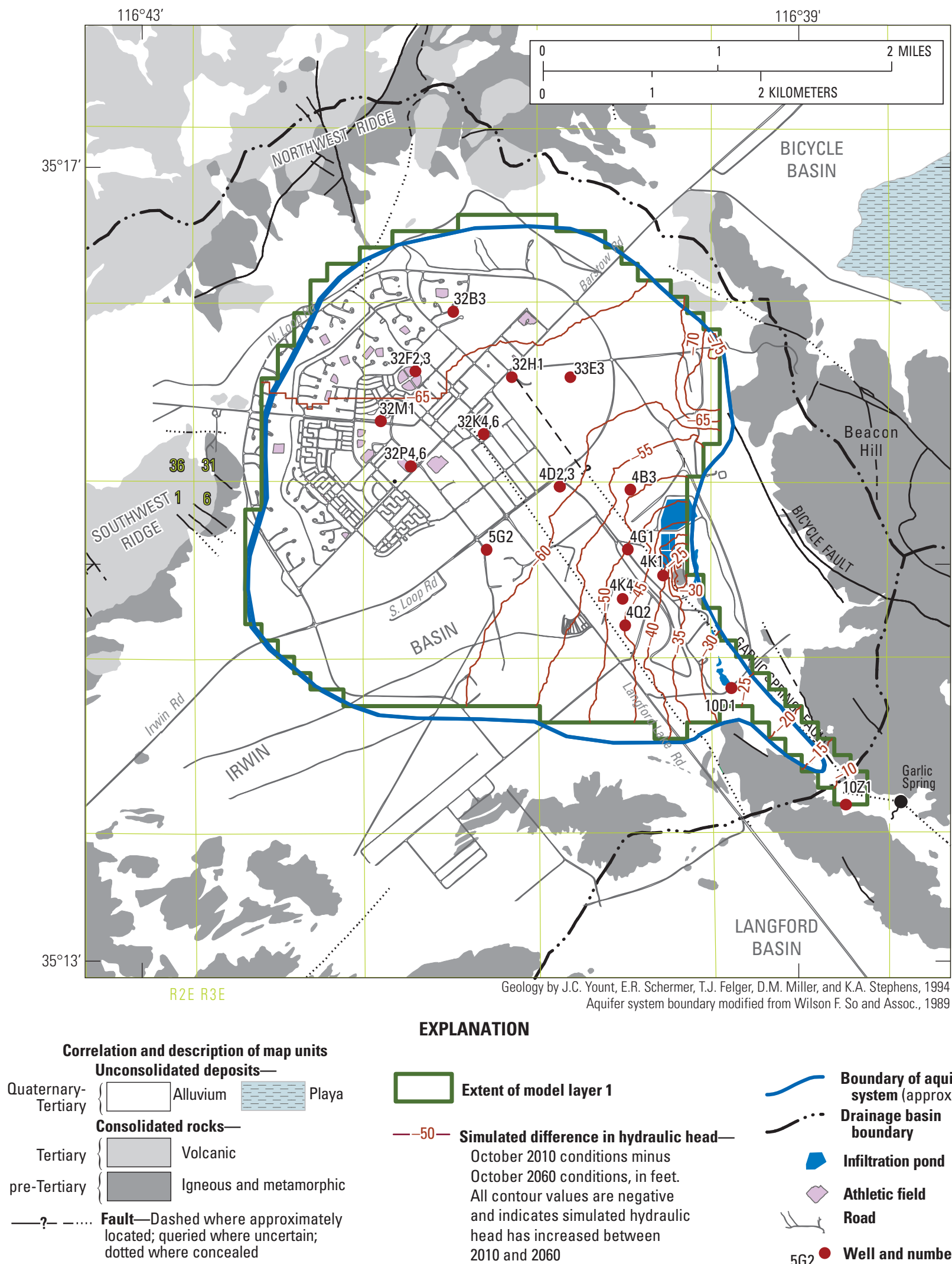

\section{EXPLANATION}
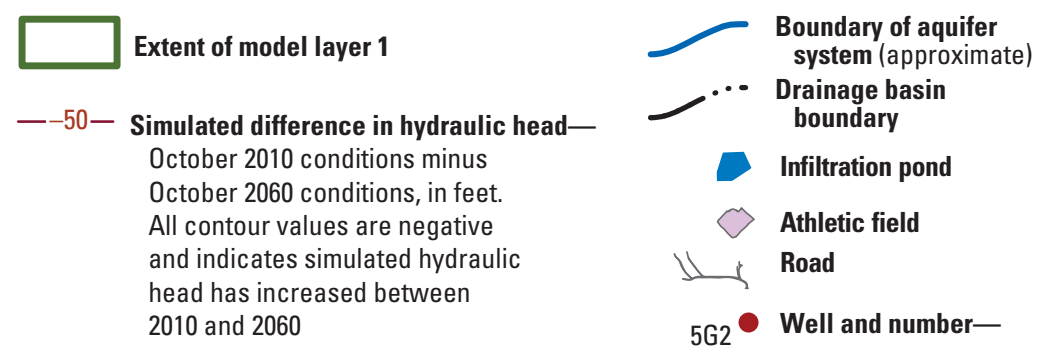

Figure 13. Simulated difference in hydraulic head from October 2010 conditions to October 2060 conditions, scenario 3, layer 1, Irwin Basin, Fort Irwin National Training Center, California. 

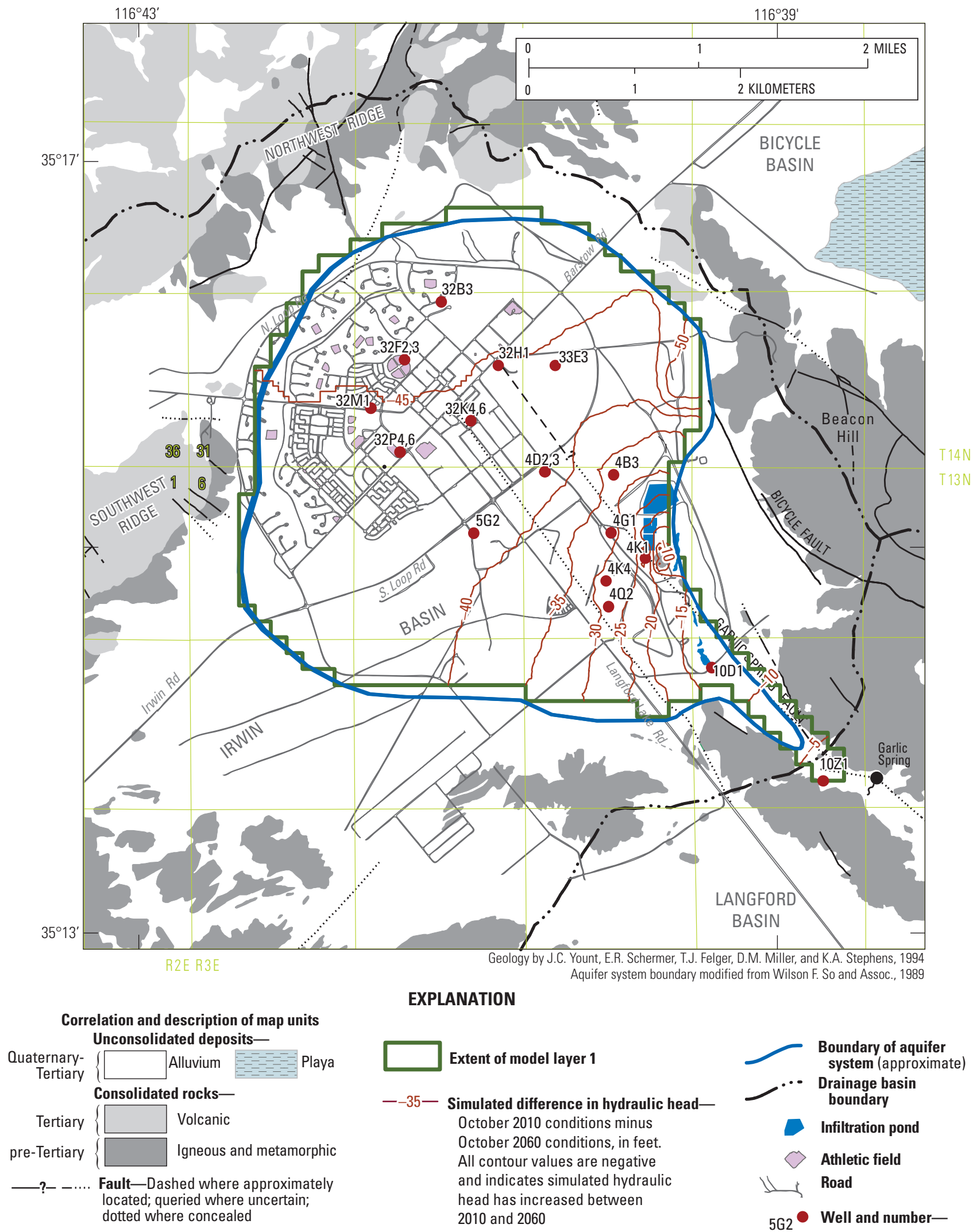

Figure 14. Simulated difference in hydraulic head from October 2010 conditions to 0 ctober 2060 conditions, scenario 4, layer 1, Irwin Basin, Fort Irwin National Training Center, California. 

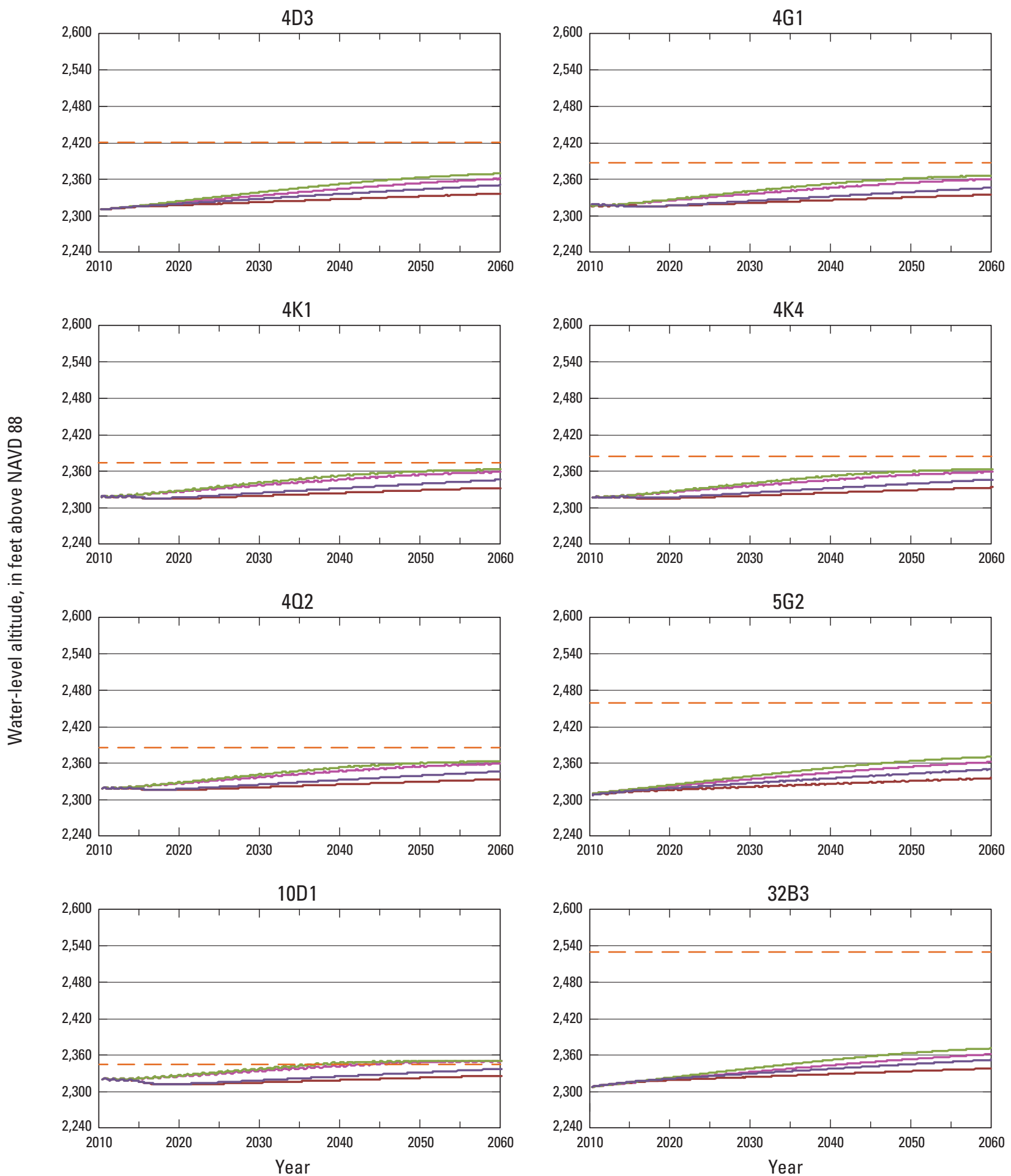

EXPLANATION

_ _ - Altitude of land surface

Simulated water level

Scenario $1 \longrightarrow$ Scenario 3

Scenario $2 \longrightarrow$ Scenario 4

Figure 15. Hydrographs of simulated hydraulic heads at 14 wells for four scenarios, Irwin Basin, Fort Irwin National Training Center, California. 

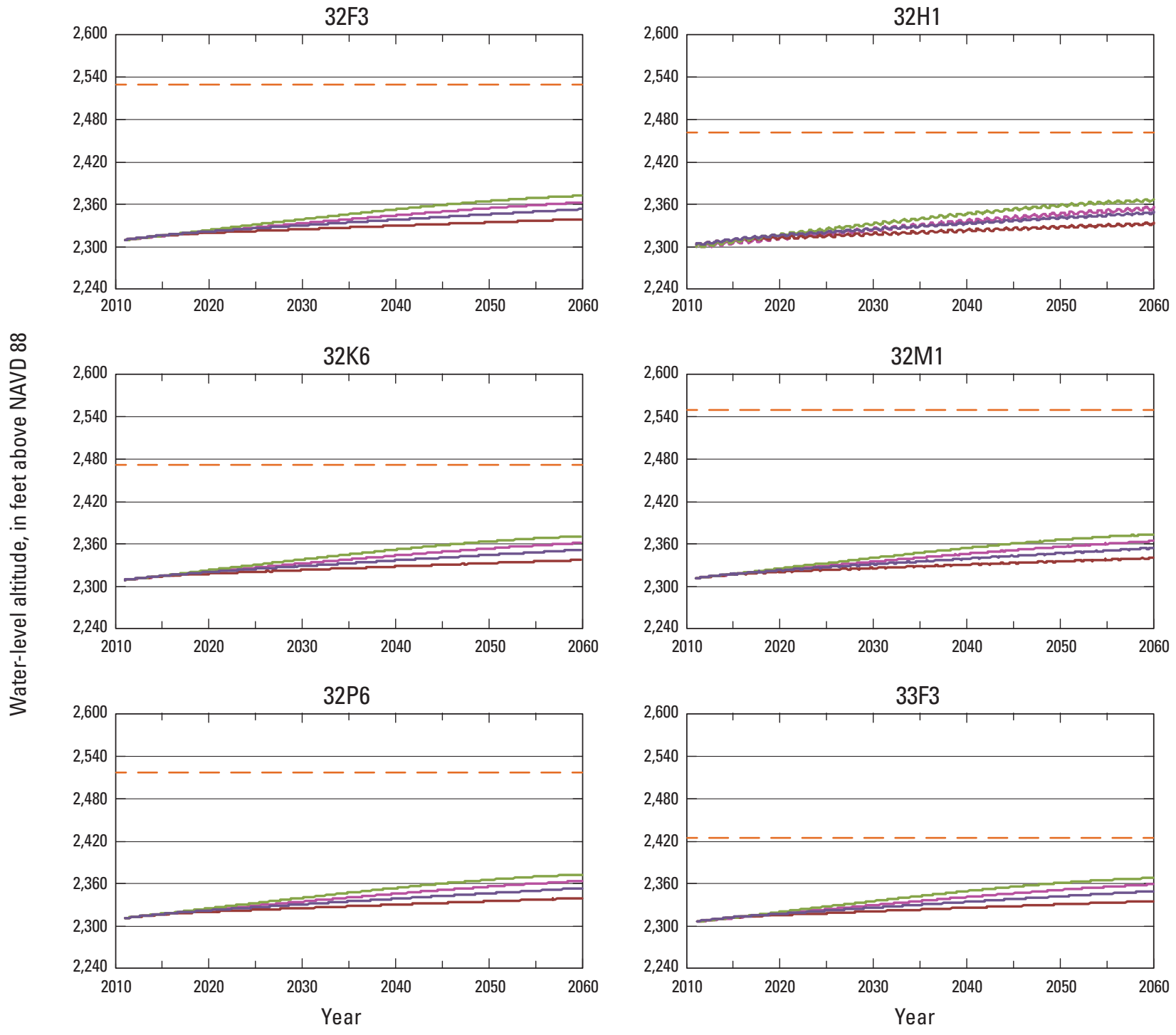

EXPLANATION

- _ - Altitude of land surface

Simulated water level

Scenario $1 \longrightarrow$ Scenario 3

Scenario $2 \longrightarrow$ Scenario 4

Figure 15. - Continued 


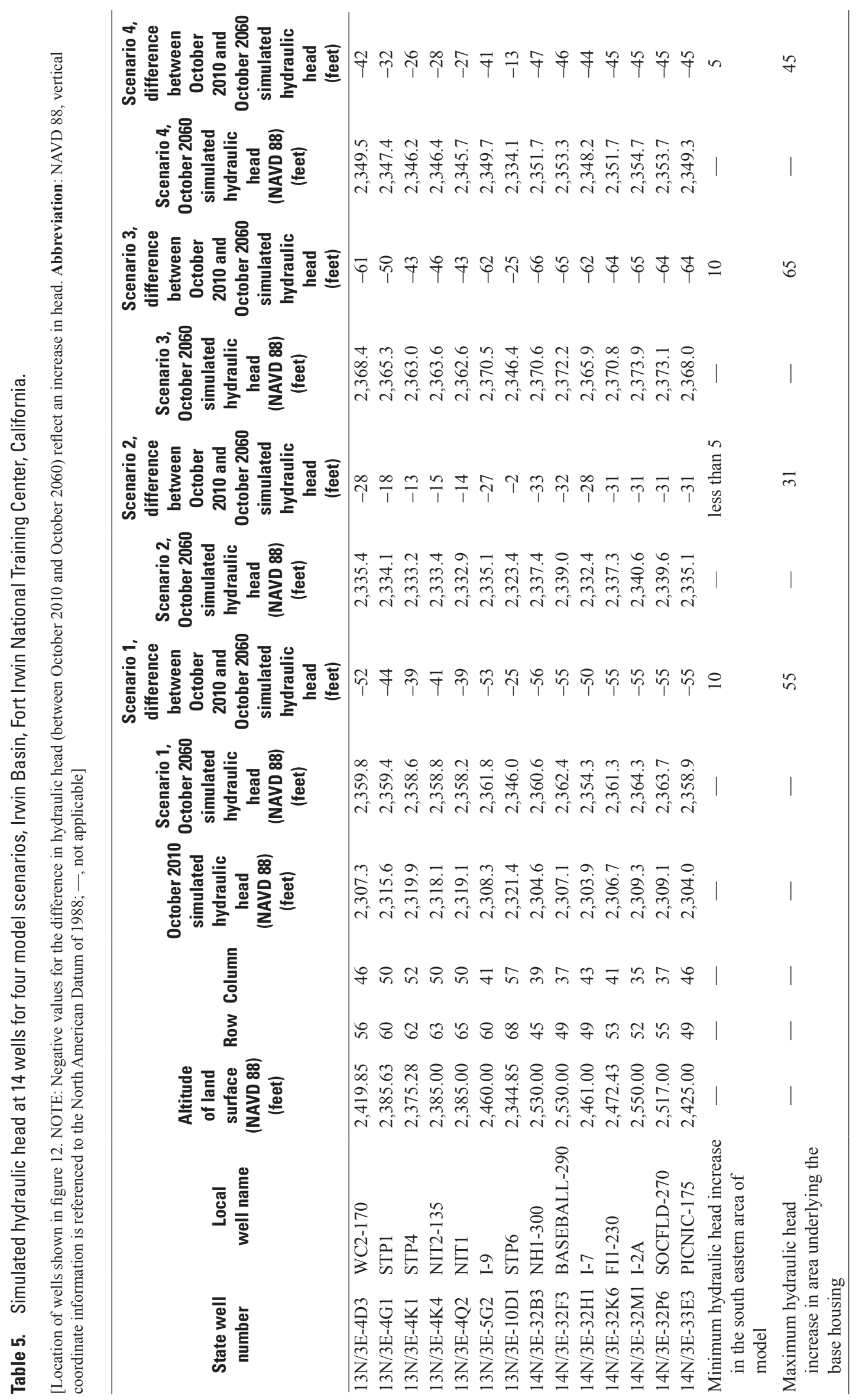


Table 6. Summary of simulated groundwater discharge to drains, Irwin Basin, Fort Irwin National Training Center, California.

[Values in acre-feet.]

\begin{tabular}{|c|c|c|}
\hline Year & Scenario 1 & Scenario 3 \\
\hline $2011-27$ & 0 & 0 \\
\hline 2028 & 0 & 1 \\
\hline 2029 & 0 & 3 \\
\hline 2030 & 0 & 5 \\
\hline 2031 & 1 & 8 \\
\hline 2032 & 2 & 11 \\
\hline 2033 & 3 & 14 \\
\hline 2034 & 6 & 19 \\
\hline 2035 & 8 & 23 \\
\hline 2036 & 10 & 26 \\
\hline 2037 & 12 & 32 \\
\hline 2038 & 15 & 39 \\
\hline 2039 & 19 & 45 \\
\hline 2040 & 22 & 51 \\
\hline 2041 & 24 & 60 \\
\hline 2042 & 28 & 78 \\
\hline 2043 & 32 & 96 \\
\hline 2044 & 37 & 115 \\
\hline 2045 & 41 & 134 \\
\hline 2046 & 46 & 153 \\
\hline 2047 & 50 & 171 \\
\hline 2048 & 56 & 189 \\
\hline 2049 & 68 & 207 \\
\hline 2050 & 82 & 225 \\
\hline 2051 & 94 & 242 \\
\hline 2052 & 107 & 259 \\
\hline 2053 & 120 & 281 \\
\hline 2054 & 133 & 304 \\
\hline 2055 & 145 & 327 \\
\hline 2056 & 157 & 350 \\
\hline 2057 & 169 & 373 \\
\hline 2058 & 181 & 394 \\
\hline 2059 & 193 & 414 \\
\hline 2060 & 205 & 432 \\
\hline
\end{tabular}

\section{Scenario 2}

Scenario 2 simulates the monthly groundwater withdrawals that were calculated for scenario 1 distributed initially between two production wells and additional withdrawals later from a third production well. The total volume of simulated groundwater withdrawals was about 28,350 acre-ft in scenario 2. Discharge to the wastewater treatment plant used to calculate recharge is estimated to decrease from 2010 values, in 4 phases. The results from the scenario 2 simulation show the least rise in groundwater levels in the Irwin Basin of the four scenarios. Groundwater levels rise about $30 \mathrm{ft}$ near the base housing to less than $5 \mathrm{ft}$ in the unnamed wash exiting Irwin Basin near well 13N/3E-10Z1S (fig. 12 and table 5). Groundwater levels remain below land surface throughout Irwin Basin (fig. 15).

\section{Scenario 3}

Scenario 3 simulated a reduction of 3 percent per year in 2010 withdrawals from 2011 to 2020 and then held withdrawals at a constant rate (30 percent less than in 2010) from 2021 to 2060 . The total volume of simulated groundwater withdrawals was reduced from about 26,800 acre-ft in scenario 1 to about 18,760 acre- $\mathrm{ft}$ in scenario 3 . The reduced recharge rate simulated in scenario 1 was used in scenario 3 . The simulated reduction in groundwater withdrawals and recharge rate at the wastewater treatment facility resulted in a rise in groundwater levels throughout the Irwin Basin. Groundwater levels rise $65 \mathrm{ft}$ in the area underlying the base housing in the northwestern part of the basin and by $10 \mathrm{ft}$ in the unnamed wash near $13 \mathrm{~N} / 3 \mathrm{E}-10 \mathrm{Z} 1$ (fig. 13 and table 5). The results from this scenario show the greatest rise in groundwater levels in the Irwin Basin of the 4 scenarios. Analysis of simulation results indicate groundwater levels will rise to land surface around the golf course pond, duck ponds and well 13N/3E-10D1 (fig. 15). Groundwater discharge to the drains, simulated around the golf course pond, duck ponds and an unnamed wash near well 13N/3E-10D1, ranges from 1 acre-ft/year in 2028 to 432 acre-ft/year by 2060 (table 6).

\section{Scenario 4}

Scenario 4 simulated a reduction of 3 percent per year in 2010 withdrawals from 2011 to 2020 distributed among 2 wells, and then a constant rate of withdrawal from 2021 to 2060. Beginning in 2016, an additional withdrawal of $31 \mathrm{acre}-\mathrm{ft} / \mathrm{yr}$ is simulated from an inactive production well $14 \mathrm{~N} / 3 \mathrm{E}-32 \mathrm{M} 1$. The total volume of simulated groundwater withdrawals was about 20,300 acre-ft in scenario 4 . The reduced recharge rate simulated in scenario 2 was used in scenario 4. Analysis of results from this simulation indicate groundwater levels rise by $45 \mathrm{ft}$ near the base housing to less than $5 \mathrm{ft}$ in the unnamed wash near 13N/3E-10Z1 (fig. 14). Groundwater levels remain below land surface in the Irwin Basin (fig. 15 and table 5). There is no simulated groundwater discharge to the drains.

\section{Model Limitations}

A numerical model is useful for testing and refining a conceptual model of a groundwater flow system, developing an understanding of the system, guiding data collection, and projecting aquifer responses to changes in aquifer stresses within specified limits. However, a model can only approximate the actual system and is based on simplified assumptions and estimated conditions. Thus, the results of model simulations are only as accurate as the input data and assumed boundary conditions used to constrain the simulations. 
As designed and calibrated, the groundwater-flow model of the Irwin Basin is best used for analyzing basin-wide issues of water use and supply. The model is particularly useful for estimating changes in groundwater levels and flows in the Irwin Basin and flows in response to groundwater withdrawal and artificial recharge. Simulated water levels at locations adjacent to active production wells may not accurately reflect water levels at these locations because simulated water levels are averaged over each model cell and reflect general trends in water levels across a broad area.

Because the model was used to test different quantities and distributions of artificial recharge, the artificial recharge estimates were as representative as possible considering the data limitations. The original model estimated artificial recharge from pumpage data because historical records on the quantities of water used for irrigation and discharged from the wastewater-treatment facility either were not available or may be inaccurate. For the model scenarios, artificial recharge at the wastewater-treatment facility ponds was estimated from 2010 metered data of the quantity of wastewater processed at the wastewater-treatment facility. Estimating artificial recharge in the ponds from the quantity of water processed at the wastewater-treatment facility may be an improvement, but more accurate estimates of artificial recharge quantities and distribution could be used to update and verify the model as they become available. More accurate estimates of artificial recharge from irrigation could be derived if the quantity of water used for irrigation was metered.

\section{Summary and Conclusions}

Fort Irwin National Training Center presently (2012) obtains its potable water supply by pumping from wells in the Irwin, Bicycle, and Langford Basins. Groundwater development began in the Irwin Basin in 1941. Pumping from the Bicycle and Langford Basins began in 1967 and 1992, respectively; pumping from these basins has resulted in a decrease in the groundwater demand from the Irwin Basin. Groundwater from Bicycle and Langford basins is imported into the Irwin Basin. Some water is used for irrigation at the base housing; the water that is not consumed is treated at the wastewatertreatment facility and discharged to infiltration ponds. Estimated groundwater recharge has exceeded groundwater withdrawals in the Irwin Basin since 1967, except for the years 1984 and 1986-91. From 1967, about 33,980 acre-ft was withdrawn from the groundwater-flow system within the Irwin Basin and an estimated 50,600 acre-ft recharged the basin, resulting in a net gain of 16,620 acre- $\mathrm{ft}$ of water to the groundwater-flow system. Reduced pumping in the Irwin Basin, recharge from irrigation at the base housing, and artificial recharge from treated wastewater at the infiltration ponds has caused water levels to stabilize or rise throughout most of the Irwin Basin.
An existing groundwater-flow model of the aquifer system in the Irwin Basin (Densmore, 2003) was updated and used to simulate flow under four alternative withdrawal and recharge conditions, here called scenarios. The updated groundwater-flow model is a useful tool to help estimate the long-term availability of groundwater from the basin by evaluating differences in groundwater-level altitudes (or water levels) among scenarios simulating different withdrawal and recharge rates. The updated model was used to evaluate the potential spatial effects on groundwater levels as a consequence of 1) continued withdrawals at the 2010 average rate of pumping, 2) supplementing water-supply needs with withdrawals from an inactive production well, and, 3) a reduction in groundwater recharge from treated wastewater. The four scenarios simulate conditions from January 2011 to December 2060. Scenario 1 simulates the 2010 annual rate of withdrawals (536 acre-ft/yr) from a production well in the Irwin Basin and remains constant from 2011 to 2060. The estimated quantity of treated wastewater discharged to the infiltration ponds near the wastewater-treatment facility for 2011 through 2060 was reduced from the 2010 values in scenario 1. Scenario 2 simulates the 2010 annual rate of withdrawals (536 acre-ft/yr) from two production wells in the Irwin Basin until 2060 and additional withdrawals of $31 \mathrm{acre}-\mathrm{ft} / \mathrm{yr}$ from an inactive well. Discharge to the wastewater treatment plant used to calculate recharge is estimated to decrease from 2010 values, in 4 phases in scenario 2. Scenario 3 simulated a reduction of 3 percent per year in 2010 withdrawals from 2011 to 2020 and then held withdrawals at a constant rate (30 percent less than in 2010) from 2021 to 2060. Scenario 3 uses the same recharge rate simulated in scenario 1 . Scenario 4 simulated a reduction of 3 percent per year in 2010 withdrawals from 2011 to 2020 distributed among two wells, and then a constant rate of withdrawal from 2021 to 2060. Beginning in 2016, an additional withdrawal of 31 acre-ft/yr is simulated from an inactive production well. The reduced recharge rate simulated in scenario 2 was used in scenario 4.

Analysis of the results from scenario 1 and 3 indicate groundwater levels rise throughout Irwin Basin. These increases were as much as $65 \mathrm{ft}$ in the area underlying the base housing in the northwestern part of the basin and $10 \mathrm{ft}$ in the southeastern area near the unnamed wash exiting the basin. The rise in water levels in the northwestern part of the basin is a result of continued recharge from irrigation at the base housing. Water levels rise to land surface around the golf course pond, duck ponds and in the southeastern area near the unnamed wash exiting the basin. Groundwater discharge to the drains, simulated around the golf course pond, duck ponds and the unnamed wash, ranges from 1 to 432 acre-ft/year by 2060 .

The results from the scenario 2 and 4 simulations show the least rise in groundwater levels in the Irwin Basin of the four scenarios. These increases were as much as $45 \mathrm{ft}$ in the area underlying the base housing in the northwestern part of the basin and $5 \mathrm{ft}$ in the southeastern area near the unnamed wash exiting the basin. Groundwater levels remain below land surface throughout the Irwin Basin in scenarios 2 and 4. 


\section{References Cited}

California Irrigation Management Information System, 2013, A program in the Office of Water Use Efficiency, California, Department of Water Resources that manages a network of automated weather stations in California: Sacramento, Calif., Department of Water Resources, Office of Water Use Efficiency, accessed on January 24, 2013, http://wwwcimis. water.ca.gov/cimis/myCimis.jsp

Densmore, J.N., 2003, Simulation of groundwater-flow in the Irwin Basin aquifer system, Fort Irwin National Training Center, California: U.S. Geological Survey Water-Resources Investigations Report 02-4264, 69 p.

Densmore, J.N., and Londquist, C.J., 1997, Groundwater hydrology and water quality of Irwin Basin at Fort Irwin National Training Center, California: U.S. Geological Survey Water-Resources Investigations Report 97-4092, 159 p.

EarthInfo, Inc., 1995, National Climatic Data Center summary of the day-West 1994: Boulder, Colo., EarthInfo, Inc., CDROM.

EarthInfo, Inc., 2000, EarthInfo CD2 reference manual-for all EarthInfo CD-ROM databases: Boulder, Colo., EarthInfo, Inc., CD-ROM.

Hsieh, P.A., and Freckleton, J.R., 1993, Documentation of a computer program to simulate horizontal-flow barriers using the U.S. Geological Survey modular three-dimensional finite-difference ground-water flow model: U.S. Geological Survey Open-File Report 92-477, 32 p.

Harbaugh, A.W., 2005, MODFLOW-2005, the U.S. Geological Survey modular ground-water model - the GroundWater Flow Process: U.S. Geological Survey Techniques and Methods 6-A16, variously paged.

Konikow, L.F., Hornberger, G.Z., Halford, K.J., and Hanson, R.T., 2009, Revised multi-node well (MNW2) package for MODFLOW ground-water flow model: U.S. Geological Survey Techniques and Methods 6-A30, $67 \mathrm{p}$.

McDonald, M.G., and Harbaugh, A.W., 1988, A modular three-dimensional finite difference groundwater flow model: U.S. Geological Survey Techniques of Water-Resources Investigations, book 6, chap. Al, $586 \mathrm{p}$.

National Oceanic and Atmospheric Administration, 1994, Climatological data, annual summary, California, 1994: Asheville, N.C., National Oceanic and Atmospheric Administration, v. 98, no. 13.

Wilson F. So and Associates, Inc., 1989, U.S. Army National Training Center at Fort Irwin, California, Water Basin Development Plan, Final Report, June 1989: 85 p.
Wilson, J.D., and Naff, R.L., 2004, The U.S. Geological Survey modular ground-water model-GMG linear equation solver package documentation: U.S. Geological Survey Open-File Report 2004-1261, 47 p.

Yount, J.C., Schermer, E.R., Felger, T.J., Miller, D.M., and Stephens, K.A., 1994, Preliminary geologic map of Fort Irwin Basin, north-central Mojave Desert, California: U.S. Geological Survey Open-File Report 94-173, 27 p. 
This page intentionally left blank. 
Prepared by the Sacramento Publishing Service Center.

For more information concerning this report, contact:

Director

U.S. Geological Survey

California Water Science Center

6000 J Street, Placer Hall

Sacramento, CA 95819

GS-W-CAWSC_WWW@usgs.gov

or visit our Web site at:

http://ca.water.usgs.gov 


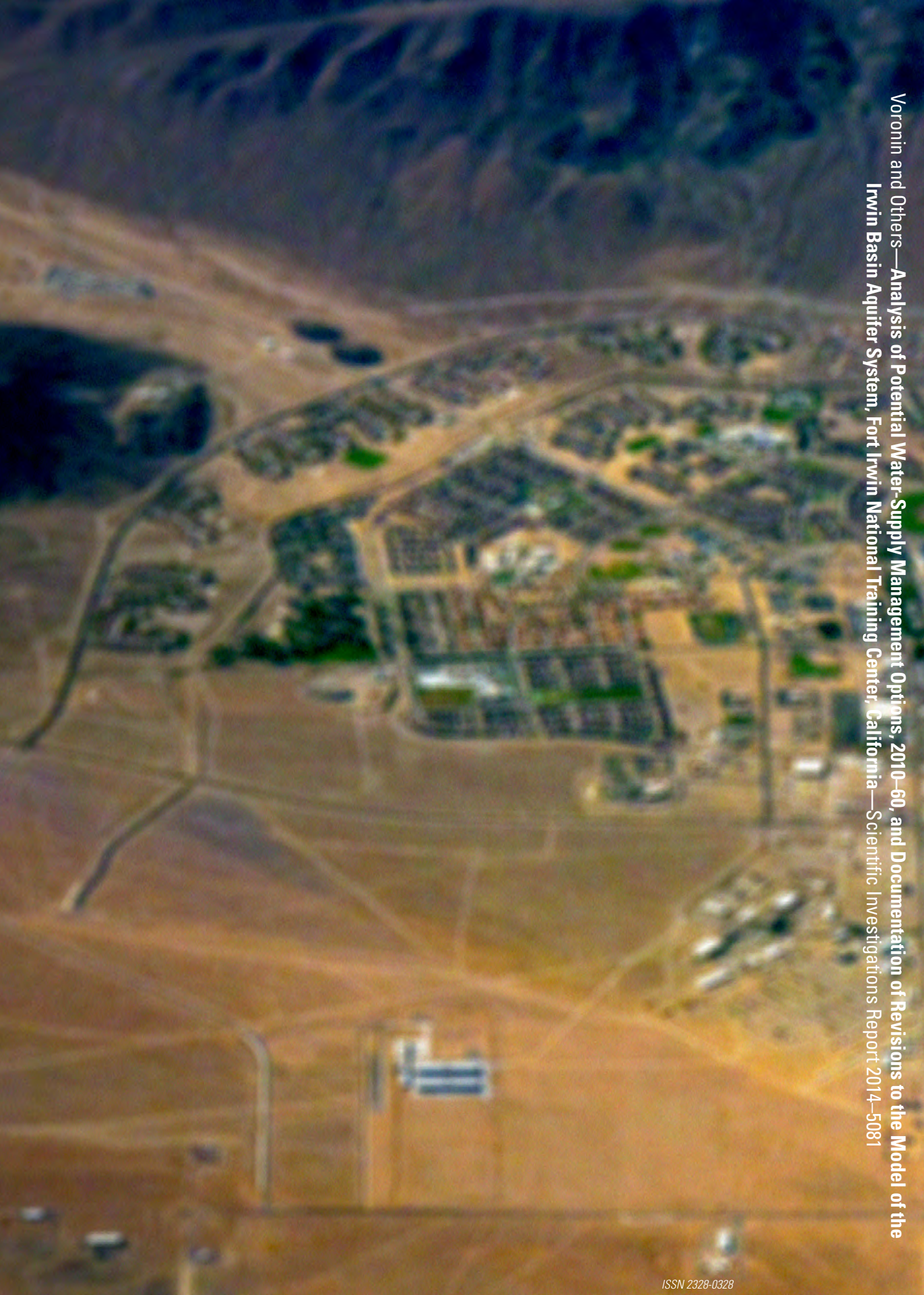

